\title{
Doppler Radar Study on the Successive Development of Snowbands at a Convergence Line near the Coastal Region of Hokuriku District
}

\author{
Hanako YOSHIHARA ${ }^{1}$ \\ Graduate School of Environmental Earth Science, Hokkaido University, Sapporo, Japan \\ Masayuki KAWASHIMA \\ Institute of Low Temperature Science, Hokkaido University, Sapporo, Japan \\ Ken-ichiro ARAI \\ Graduate School of Environmental Earth Science, Hokkaido University, Sapporo, Japan \\ Jun INOUE \\ School of Earth and Atmospheric Sciences, Georgia Institute of Technology, Atlanta, U.S.A. \\ and \\ Yasushi FUJIYOSHI \\ Institute of Low Temperature Science, Hokkaido University, Sapporo, Japan \\ Frontier Research System for Global Change, Yokohama, Japan
}

(Manuscript received 29 September 2003, in revised form 5 April 2004)

\begin{abstract}
During the field experiment of winter mesoscale convective systems over the Sea of Japan in 2001 (WMO-01), several snowbands associated with a cold front developed remarkably at 10 30 km off the coast of Hokuriku district on 28 and 29 January 2001. Dual-Doppler radar analysis was made to investigate the mechanisms responsible for the successive development of the snowbands.

Derived wind fields revealed that a mesoscale convergence line was formed between the prevailing westerly and shallow ( $\sim 1 \mathrm{~km}$ depth), cold southwesterly winds that blew from inland toward Toyama bay. As the downshear-tilting convective cells in the snowbands approached the convergence line, they became almost upright and their height increased from $4 \mathrm{~km}$ to $6 \sim 7 \mathrm{~km}$. The edge of the southwesterly cold air temporarily became indistinct because of the entrainment of the air into the convective cells that developed aloft. However, the subsequent advection of the cold southwesterly reestablished the convergence line, and enabled the successive development of following snowbands.
\end{abstract}

Corresponding author: Masayuki Kawashima, Institute of Low Temperature Science, Hokkaido University, Sapporo 060-0819, Japan.

E-mail: kawasima@lowtem.hokudai.ac.jp

1 Present affiliation: Osaka District Meteorological Observatory, Osaka, Japan.

(C) 2004, Meteorological Society of Japan

\section{Introduction}

During cold air outbreaks in winter, snow clouds bring heavy snowfalls to the southeastern coastal region of the Sea of Japan. Many 
previous studies have noted that the modification of snow clouds before landing plays an important role in the precipitation features in the downwind region (e.g., Isono et al. 1966a and b; Takeda et al. 1982; Murakami et al. 1994; Saito et al. 1996). Modifications of convective clouds near the coast are popular phenomena, and are reported in many other regions (e.g., Hsu 1988; Braun et al. 1997; Kanada et al. 1999). These studies pointed out that differences of temperature, humidity and surface roughness between the sea and the land, and the steepness of the coastal topography directly affect the behavior of convective clouds.

Doppler radar studies have also revealed that the land-originated local wind (or "land breeze') near the coast affects the formation, maintenance and transformation of the snow clouds in the coastal region facing the Sea of Japan (e.g., Fujiyoshi et al. 1988; Ishihara et al. 1989; Tsuboki et al. 1989a and b). Along the coast of the Hokuriku district, a line of discontinuity in wind direction often forms between the northwesterly monsoon and the southerly or southwesterly from inland, and has been related to heavy snowfall around it. The line, called 'the Hokuriku discontinuity line', usually forms under mild cold air outbreaks (Japan Meteorological Agency, hereafter abbreviated as JMA, 1968) and/or when a upper cold vortex is located over the Sea of Japan (Miyazawa 1968). It has been suggested that the thermal effect caused by the temperature difference between the land and the sea, or the dynamical effect of the inland topography causes the discontinuity in wind fields. Niigata Local Meteorological Observatory (1999; hereafter NLMO) studied the snowfall pattern associated with the Hokuriku discontinuity line, and reported the synoptic and mesoscale conditions favorable for the formation of line. NLMO also tried to simulate the wind fields when snowbands formed off the coast of the Sea of Japan by using the Limited Area Model of JMA. To date, however, neither the detailed structure of the discontinuity line, nor its possible effect on the snow clouds have been elucidated.

In the winter of 2001, the field observation called 'WMO-01' (Winter Mesoscale convective systems Observations over the Japan Sea in 2001) (Yoshizaki et al. 2001) was conducted around the coastal region of Hokuriku district

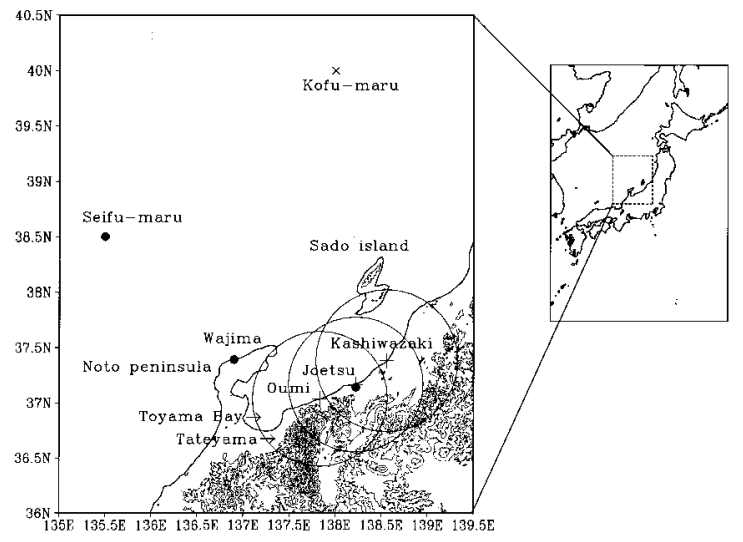

Fig. 1. Map of the WMO-01 domain with the topography shown by the contour lines at $500 \mathrm{~m}$ intervals (left). The location of each Doppler radar and its observational range are shown by the crosses and the open circles, respectively. The dots show the location of radiosonde sites at Wajima, Joetsu, and the research vessel Seifu-maru. The location of the research vessel Kofu-maru is marked by $\times$.

(Fig. 1). Its purpose was to understand the mechanism of the occurrence and development of snow clouds over the Sea of Japan. Three research vessels, two research aircraft, seven ground-based Doppler radars, and three wind profilers were deployed (see the next section). During WMO-01, banded radar echoes parallel to the coast line were frequently observed. Eito et al. (2003) numerically simulated the quasistationary snowband that developed along a mesoscale convergence line on 16 January, 2001. They discussed the maintenance process of the snowband, paying special attention to the role and formation mechanism of a cold pool beneath the snowband.

On 28 and 29 January, 2001, several snowbands associated with a cold front showed remarkable enhancement within the observational range of the Doppler radars. The Doppler-derived wind field revealed a line of discontinuity in wind direction $10 \sim 30 \mathrm{~km}$ off the coast, on which radar echoes of snowbands were remarkably enhanced. In contrast to Eito et al. (2003), the purpose of this study is to show the structural changes of snowbands as they approach the coast, and to discuss the 
(a)

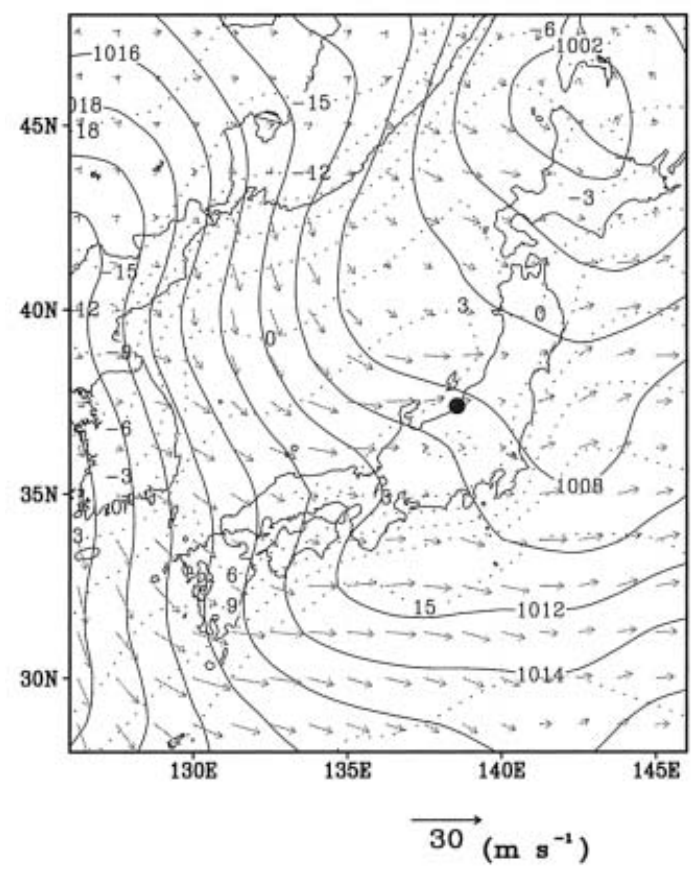

(b)

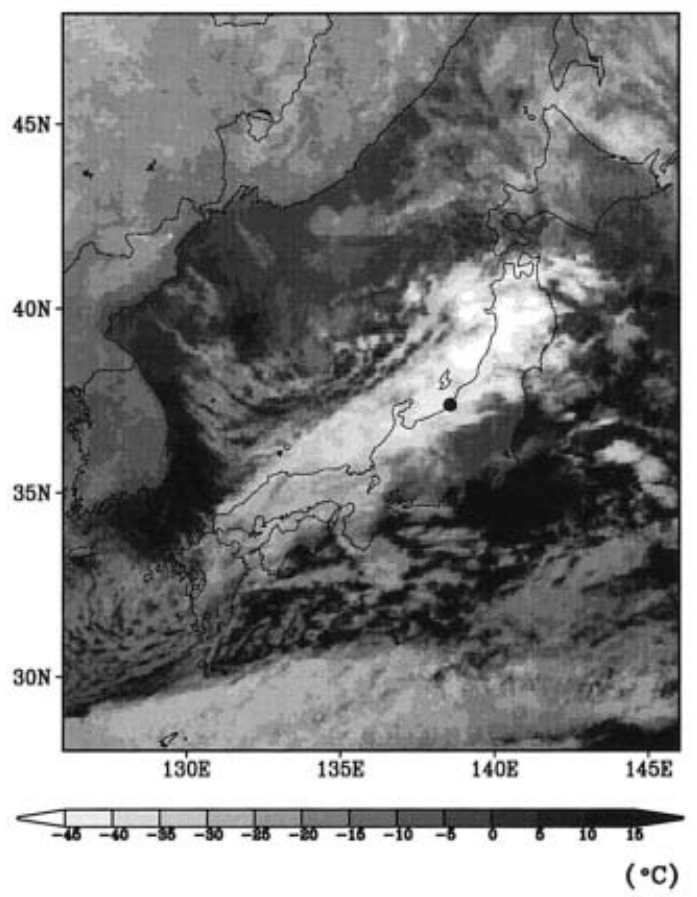

Fig. 2. (a) Sea-level pressure and temperature fields at 21 LST on 28 January 2001. The solid lines are the isobars at $2 \mathrm{hPa}$ intervals and the dotted lines are the isotherms at $3^{\circ} \mathrm{C}$ intervals. Surface wind fields are also depicted by the vectors. (b) GMS satellite IR1 image for the same time.

mechanisms responsible for their successive enhancement, mainly based on the multiple Doppler radar data.

This paper is organized as follows. An overview of the observational setting and data used in this study is given in section 2 . Section 3 shows the synoptic situation. Section 4 provides the observational evidence of the successive evolution of the snowbands and associated transformation of the convergence line. Causes of the convergence line and the mechanisms responsible for successive enhancement of the snowbands are discussed in section 5. Finally, section 6 provides a summary and conclusions of this study.

\section{Observational setting and data}

The WMO-01 observations were performed synthetically over the land, sea and in the air mainly around the coastal region of Hokuriku district (see Fig. 1) facing the Sea of Japan (see
Yoshizaki et al. (2001) for the detailed framework and contents of this observation).

The period of observation was from the beginning of January to the beginning of February, 2001, including two intense observational periods (IOPs) (12-19 January and 25 January-1 February).

During the IOPs, seven Doppler radars were deployed along the coast and operated continuously. The ILTS (Institute of Low Temperature Science, Hokkaido Univ.) Doppler radar and two NIED (National Research Institute for Earth Science and Disaster Prevention) Doppler radars were deployed at Kashiwazaki, Joetsu and Oumi, respectively (Fig. 1). The maximum detection ranges of the ILTS radar and the two NIED radars were $68 \mathrm{~km}$ and $64 \mathrm{~km}$, respectively. The operations of the radars were coordinated and each repeated a volume scan at 6-minute intervals. Doppler velocity and radar reflectivity were interpolated into 
the Cartesian grid with $500 \mathrm{~m}$ horizontal and $250 \mathrm{~m}$ vertical grid spacing after the moving correction of the radar echoes by using the method of Gal-Chen (1982). The dual-Doppler analysis were made using two pairs of Doppler radar data; the data obtained by Oumi and Joetsu radars, and the data obtained by Joetsu and Kashiwazaki radars, respectively. The three-dimensional wind field was obtained following the method introduced by Armijo (1969). We assumed that precipitation particles were dominated by graupels over the sea, while snow particles dominated over the land. The terminal fall speed for graupel given by Hauser and Amayenc (1986) was used in the calculation of average fall speed of precipitation particles over the sea, while it was set to be $1.0 \mathrm{~ms}^{-1}$ over the land.

GMS satellite imagery and the composite of precipitation radar data of JMA in the eastern Hokuriku district (which cover the observational area) were used to investigate the distribution of snow clouds in the wide range. Upper air sounding was performed every 6 hours at many locations and research vessels during the IOPs. The sounding data at Joetsu, Wajima and Seifu-maru were used in our analysis (the location of each site is marked in Fig. 1). Meteorological data from research vessels Seifumaru and Kofu-maru, and AMeDAS (Automated Meteorological Data Acquisition System) ten-minutely data of JMA along the coast of Hokuriku district were also used to investigate the environmental conditions.

\section{Synoptic situation}

Akiyama (1981a, b) classified snowfall distribution in this region into mountain type and plain type, and identified synoptic situations corresponding to these two types. The surface pressure in Fig. 2a shows a typical pattern for the plain type (see also NLMO). Under this pressure pattern, westerly winds prevailed around the coastal region of Hokuriku district. A meso- $\alpha$-scale low and an accompanying cold front passed over the Sea of Japan and the observation area from about 15 LST on 28 January to 03 LST on 29 January $(\mathrm{LST}=\mathrm{UTC}+9$ hours). Figure $2 \mathrm{~b}$ shows the GMS IR1-image at 21 LST on 28 January, when the eastern boundary of the cloud system associated with the cold front had just arrived at Kashiwazaki

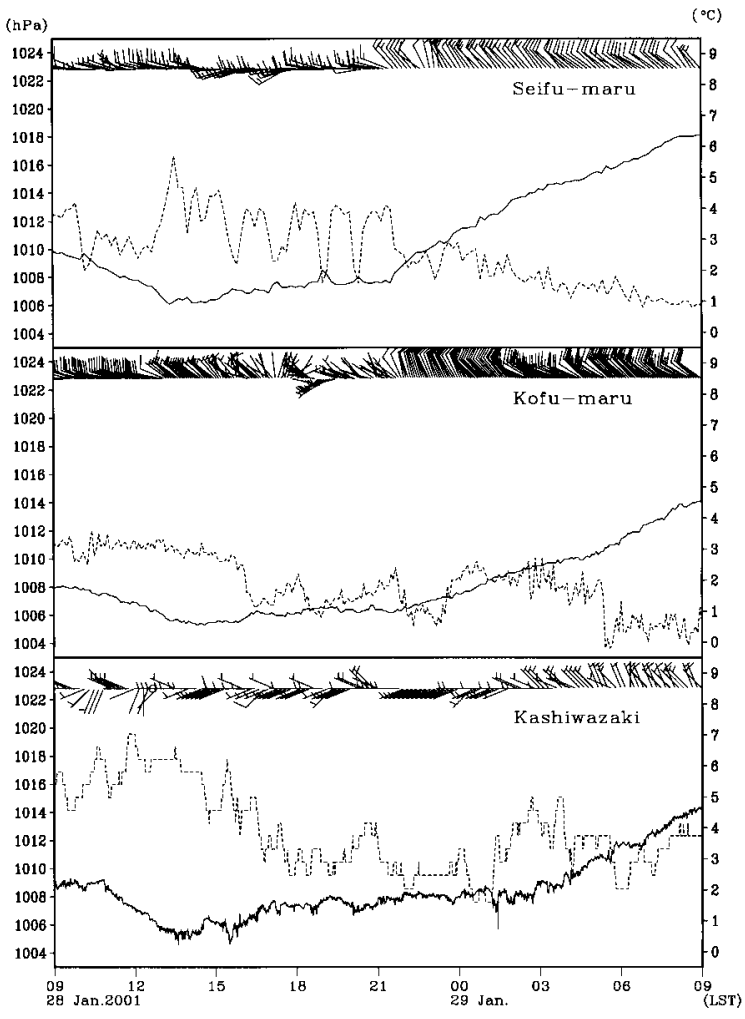

Fig. 3. Time series of the surface pressure (solid line), temperature (short dashed line) and wind barb from 09 LST on 28 January to 09 LST 29 January at Seifu-maru (top), Kofu-maru (center) and the radar site at Kashiwazaki (bottom). A half barb indicates $5 \mathrm{~m} \mathrm{~s}^{-1}$, a full barb $10 \mathrm{~m} \mathrm{~s}^{-1}$.

radar site. Several snowbands were embedded within this frontal cloud system and passed over the radar site from about 23 LST on 28 January to 02 LST on 29 January, 2001.

Time variations of surface pressure, temperature, wind direction and wind speed during the passage of this frontal system observed at Kashiwazaki, Seifu-maru and Kofu-maru are shown in Fig. 3. The surface pressure at all three sites showed minima at 13 or 14 LST on 28 January, and then increased gradually. The surface pressure began to rise at 22 LST at Seifu-maru and Kofu-maru, and at 03 LST on 29 January at Kashiwazaki. At that time, the wind direction at each point changed suddenly from west-northwesterly or west-southwesterly to north-northwesterly, and the air tempera- 
(a)

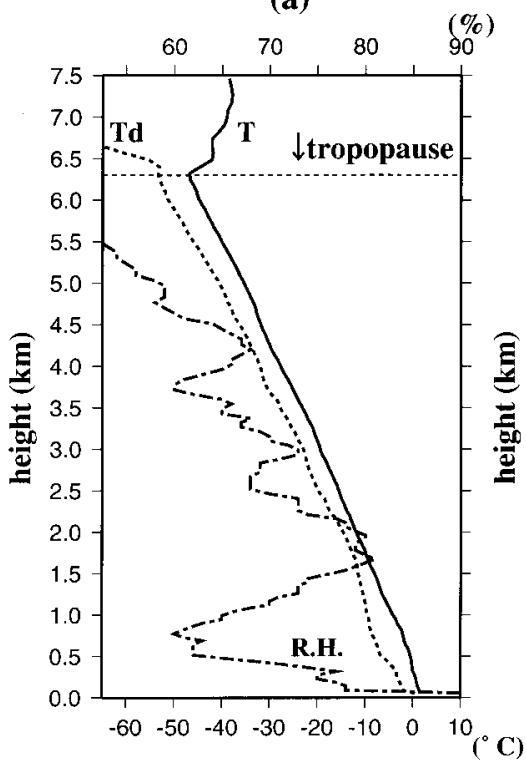

(b)

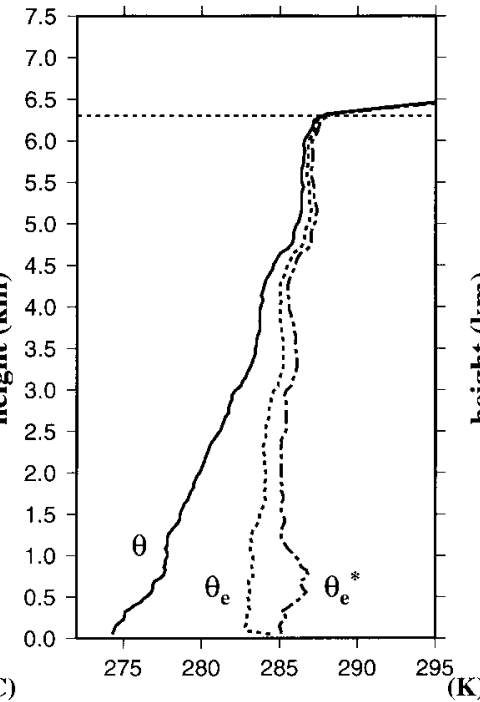

(c)

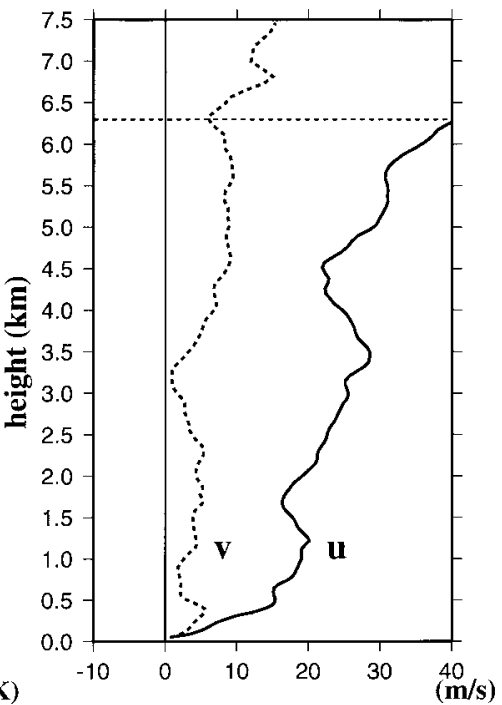

Fig. 4. Vertical profiles of (a) temperature (solid line), dew point temperature (dotted line), relative humidity (dashed line), (b) potential temperature (solid line), equivalent potential temperature (dotted line), saturated equivalent potential temperature (dashed line), (c) $u$ (solid line) and $v$ (dotted line) at 00 LST on 29 January at Joetsu.

ture at Seifu-maru and Kofu-maru began to decrease. These facts clearly indicate the passage of a cold front and the outbreak of cold air.

Vertical profiles of thermal properties and wind component at Joetsu at 00 LST on 29 January (Fig. 4) show that the layer below $1.5 \mathrm{~km}$ was relatively dry, and the layer below $0.8 \mathrm{~km}$ was absolutely stable $\left(\frac{\partial \theta_{e}^{*}}{\partial z}>0\right)$. Strong southwesterly or west-southwesterly winds prevailed in the lower layer. Particularly, southerly component was rather strong below $500 \mathrm{~m}$.

The sounding data at Joetsu at 21 LST on 28 January showed similar features (not shown), except that the cold, stable layer was slightly thinner. This indicates that the stratification and wind field kept the same character, at least during the passage of the frontal system.

\section{Successive development of the snowbands at the mesoscale convergence line}

\subsection{Temporal change of snowbands}

At around 22 LST on 28 January, three snowbands $20 \sim 30 \mathrm{~km}$ in width and about
$200 \mathrm{~km}$ in length successively formed about $70 \mathrm{~km}$ offshore and moved southeastward. The time variation of the horizontal distribution of the radar echo shows that the first snowband (I) rapidly developed near the coast from 2300 to 2350 LST (Fig. 5). Similar enhancement of the radar reflectivity was also seen for the following two snowbands (II and III) from 0000 to 0040 LST and from 0050 to 0120 LST on 29 January, respectively. Convective echoes embedded in the snowbands became weak as they moved from southwest to northeast, and turned to stratiform type after landing.

Figure 6 shows the horizontal and vertical cross sections of band I when it was located offshore, inshore, and over the land, respectively. Hereafter, a coordinate system with along-band $\left(x^{\prime}\right)$ and band-normal $\left(y^{\prime}\right)$ axes is adopted. The along-band component wind is denoted as $u^{\prime}$, and the across-band component as $v^{\prime}$. When band I was located offshore, the echo top height was about $4 \mathrm{~km}$ and the maximum reflectivity of convective clouds was generally lower than $30 \mathrm{dBZ}$. However, when the snowband approached the coast, convective clouds developed up to $6 \sim 7 \mathrm{~km}$ and their maximum reflectivity 

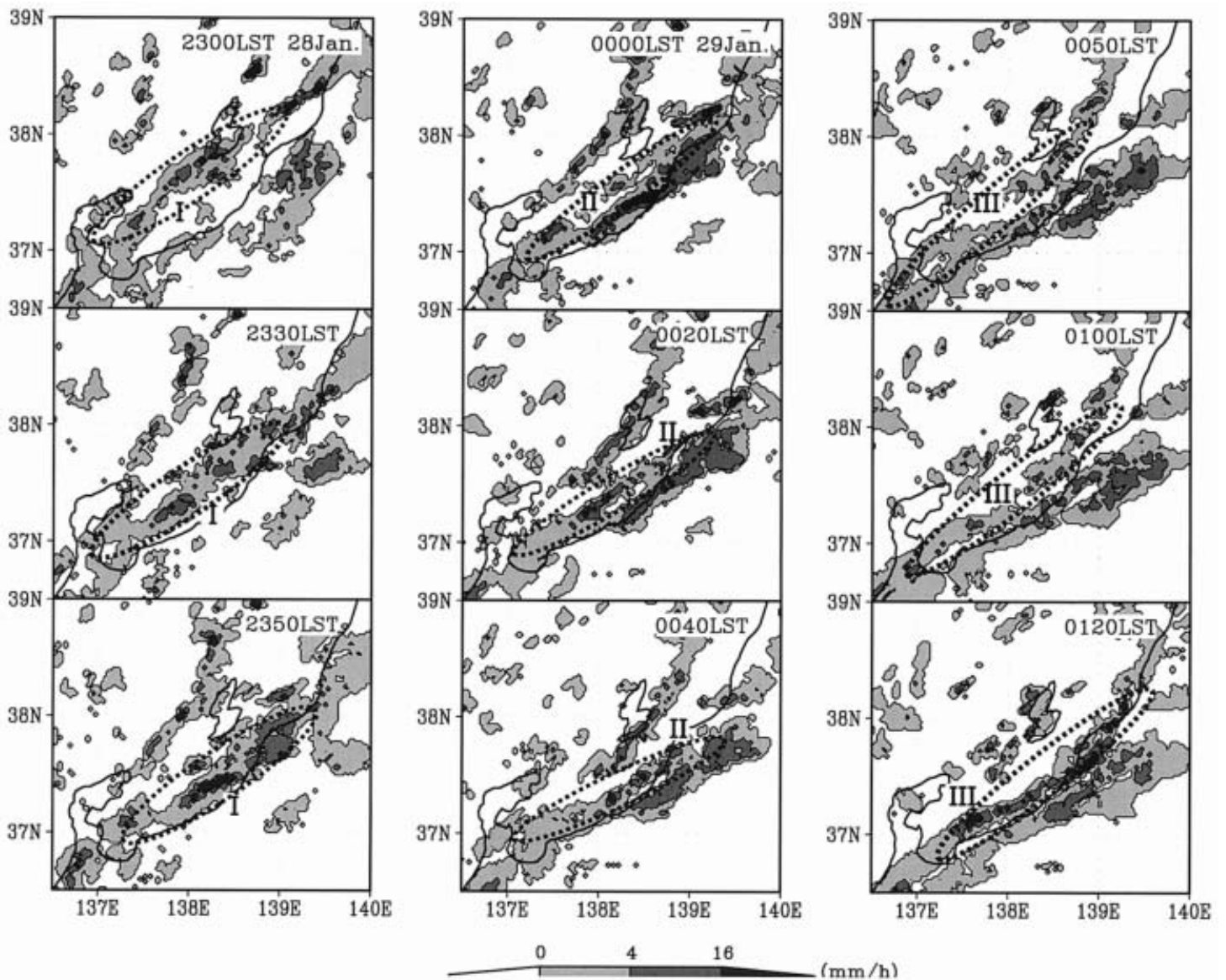

Fig. 5. Time series of the composite of JMA radar in the eastern part of Hokuriku district. The three snowbands are circled and labeled from I to III.

exceeded $40 \mathrm{dBZ}$. After landing, the radar echo type changed from convective to stratiform, and the height of the radar echo top became as low as $4 \sim 5 \mathrm{~km}$. In the following, the change in radar echo structure of the snowbands is described in detail.

Temporal variations of maximum radar reflectivity at each altitude observed by the Kashiwazaki radar are shown in Fig. 7. The Kashiwazaki radar stopped observation at 0118 LST on 29 January because of system trouble. The altitude of maximum reflectivity, which generally correlates with the vertical velocity within the convective cells, is also shown by dots.

Here, the rectangular region that encircles each snowband, with lengths $L_{x}^{\prime}=96 \mathrm{~km}$ and $L_{y}^{\prime}=40 \mathrm{~km}$ for band I, and $L_{x}^{\prime}=96 \mathrm{~km}$ and
$L_{y}^{\prime}=30 \mathrm{~km}$ for band II and III in the $x^{\prime}-y^{\prime}$ coordinates, is regarded as the band region and the above values were derived within these regions (see Fig. 6b).

The altitude of maximum reflectivity rose to its highest altitude at 2336 LST on 28 January (band I), 0012 LST (band II) and 0112 LST on 29 January (band III), when each snowband was located about $10 \mathrm{~km}$ offshore. The analysis of wind fields reveal that the abrupt enhancements of updraft velocity occurred at almost the same place (not shown). A maximum reflectivity larger than $45 \mathrm{dBZ}$ implies the existence of graupels. In fact, graupels having $2 \mathrm{~mm}$ diameter, and lightning were observed at the radar site of Kashiwazaki during the passage of the bands. After landing, the level of maximum reflectivity descended and the reflec- 
(a)

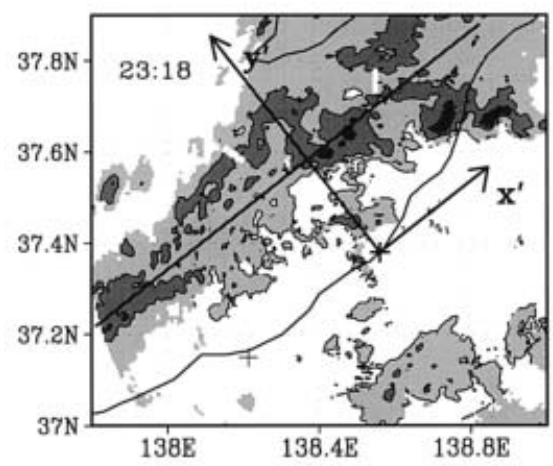

(b)

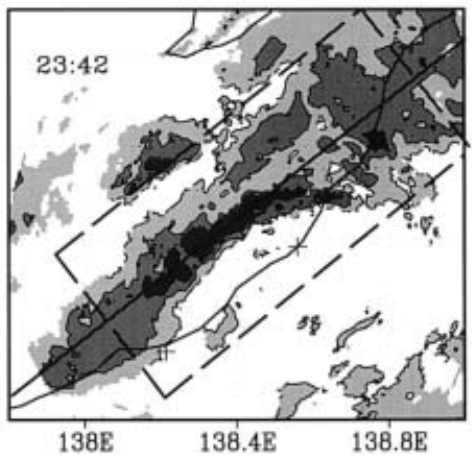

(c)

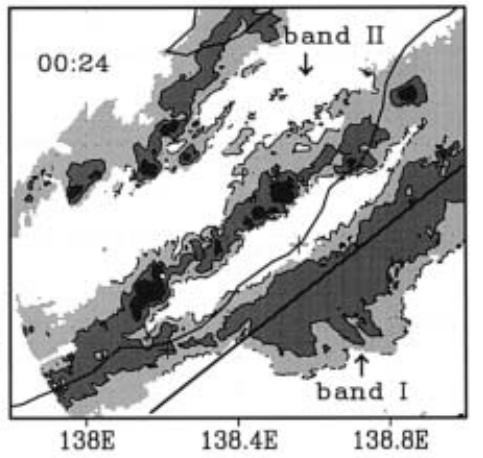

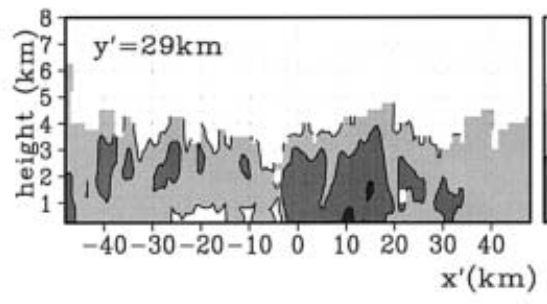
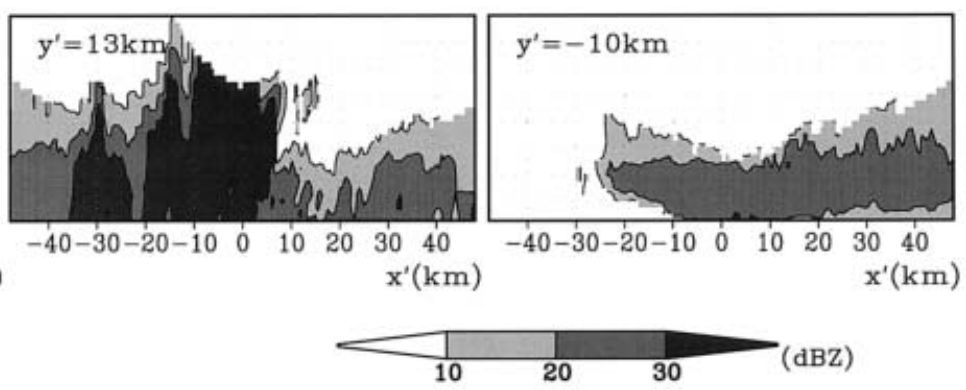

Fig. 6. Horizontal cross sections at $2 \mathrm{~km}$ altitude (upper) and vertical cross sections along band I (lower) derived from the Kashiwazaki Doppler radar data. The solid lines in the upper figure show the location of the vertical cross section of the lower figures. The axes of band parallel $\left(x^{\prime}\right)$ and band normal $\left(y^{\prime}\right)$ shown in this figure are used hereafter as the coordinate system. The rectangular region shown by the dashed line in (b) shows the example of the band region used for deriving maximum radar reflectivity in Fig. 7 .

tivity became weaker. These observational results correspond well with previous observational and numerical studies (e.g., Takeda et al. 1982; Fujiyoshi et al. 1992; Harimaya and Sato 1992; Harimaya and Kanemura 1995; Mizuno 1992; Murakami et al. 1994).

Next, to investigate the enhancement of the snowbands quantitatively, the precipitation water content (PWC) in the bands was calculated. PWC was derived by first converting the radar reflectivity factor $Z$ for each grid to the snowfall rate $R$ using the empirical formula $Z=554 R^{0.88}$ (Fujiyoshi et al. 1990). Next, $R$ was converted into precipitation water content PWC by using an empirical formula shown in Yagi et al. (1979). Here, the empirical relation for graupels was used in the calculation of PWC over the sea, whereas that for snowflakes was used over the land in the latter procedure. Fig- ure 8 shows the time-longitude cross section of the vertically integrated PWC (VIPWC) at latitude $37.45^{\circ} \mathrm{N}$ (near Kashiwazaki). VIPWC in each band began increasing at about $20 \mathrm{~km}$ offshore, and reached its peak value at about $10 \mathrm{~km}$ offshore (the bold dotted line in Fig. 8). This indicates that the rapid growth of precipitation particles occurred just before the landing. VIPWC suddenly decreased as the snowbands landed, suggesting that most of the large precipitation particles fell near the coast.

Figure 9 shows the time series of radar reflectivity at an altitude of $250 \mathrm{~m}$ (left) and VIPWC (right) from 2318 to 2348 LST in the $x^{\prime}-y^{\prime}$ coordinates. A region with strong radar reflectivity extended from southwest to northeast as the snowband approached the coast. There were several convective cells, labeled from "a" to "g", within it. The moving speed of 

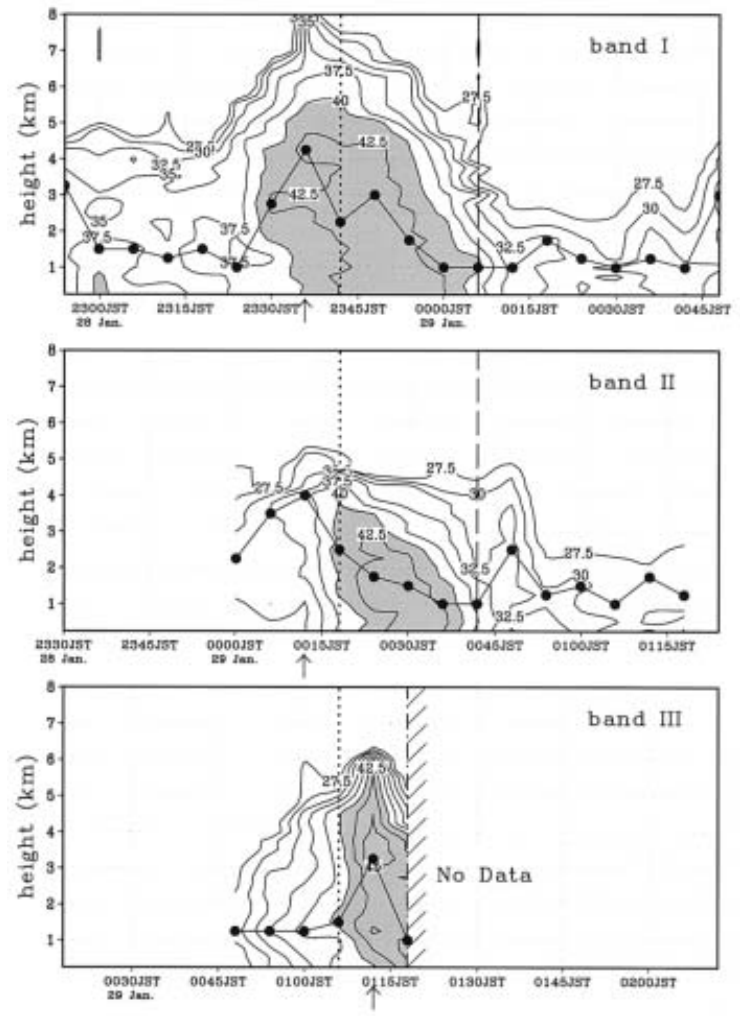

Fig. 7. Time series of the isocontour of the maximum radar reflectivity observed by the Kashiwazaki radar. Reflectivities greater than $40 \mathrm{dBZ}$ are shaded gray. The altitude of maximum reflectivity ( $\bullet$ ) for the band I, II and III from 2254 LST on 28 January to 0118 LST on 29 January is also shown. The maximum radar reflectivity and the altitude of maximum reflectivity were derived within the rectangular region shown in Fig. 6. Arrows in the abscissa show the time at which each snowband reached its mature stage. The time at which each snowband reached about $10 \mathrm{~km}$ offshore and the coast are shown by the dotted and dashed lines, respectively. Data after 0118 LST on 29 January are missing.

each cell was almost the same, and was about $19 \mathrm{~m} \mathrm{~s}^{-1}$ to the east and about $1 \mathrm{~m} \mathrm{~s}^{-1}$ to the north, which corresponds to the speed of the ambient wind at about $2 \mathrm{~km}$ altitude. The lifetime of each convective cell was rather short (30 40 minutes), and new convective cells developed one after another to the northeastern

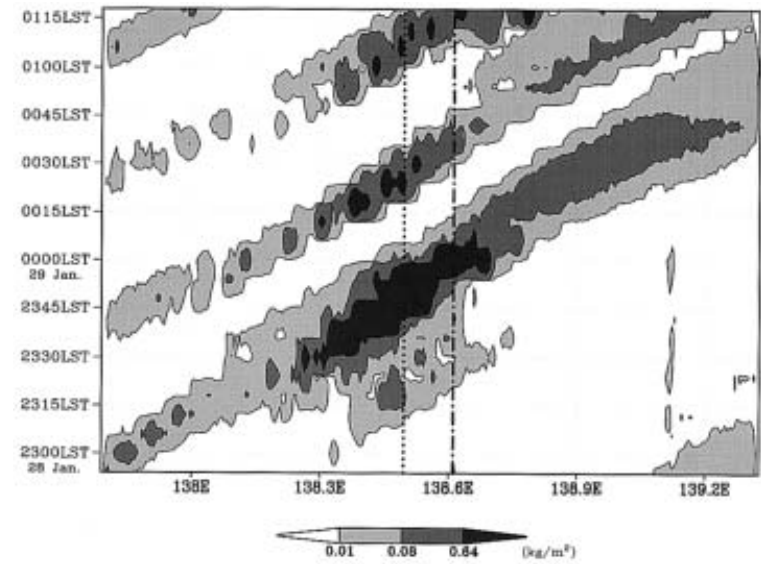

Fig. 8. Time-longitude cross section of the VIPWC (vertically integrated precipitation water content) at $37.45^{\circ} \mathrm{N}$ (near Kashiwazaki). The bold dotted and dashed lines show the locations of $10 \mathrm{~km}$ offshore and the coast, respectively.

side (leeward) of an older cell. The moving speed of each cell was almost half that of the region of maximum VIPWC in the band (shown by an arrow in Fig. 9), as listed in Table 1. This result indicates that the extension of the strong reflectivity area to the northeast was not due to the movement of strong convective cells, but due to the successive development of new convective cells on the northeastern side.

Several different explanations have been offered for periodic generation of convective cells in mesoscale convective systems. For example, Hane et al. (1987) hypothesized that periodic enhancement of convergence at the gust front, a manifestation of the previous cell's downdraft, could control timing of new cell generation. In such a case, the time interval for cell regeneration should not be much different from the lifetime of each convective cell. It should be noted that five cells (cells $\mathrm{c} \sim \mathrm{g}$ ) develop within 12 min from 2324 to 2336 LST in Fig. 9. The fact that the time interval for cell generation was much shorter than the lifetime of each cell suggests that preexisting convergence of larger scale, rather than the convergence caused by the outflows from old convective cells, were probably responsible for the successive development of each convective cell. In the next section, dual-Doppler radar data is analyzed to 


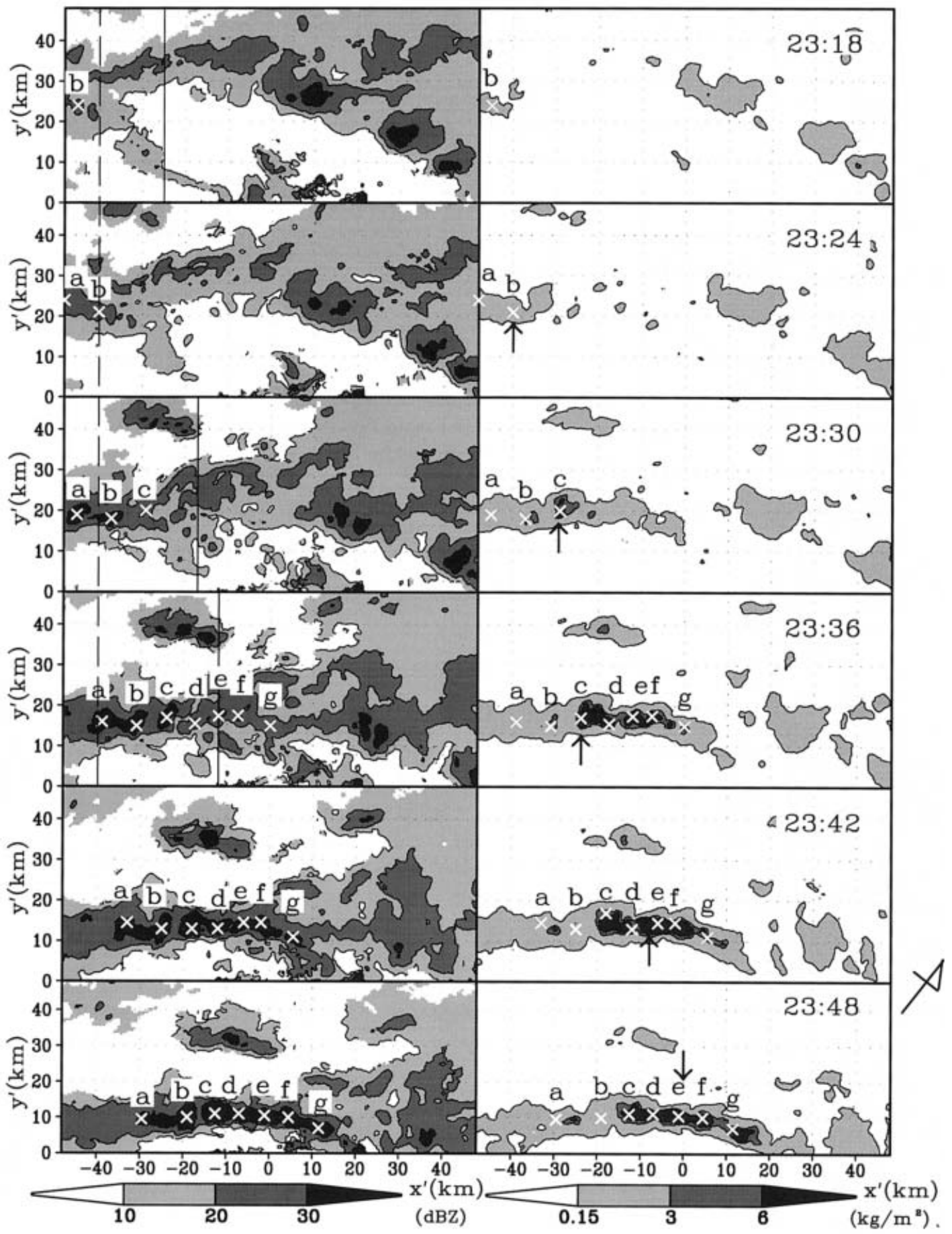

Fig. 9. Time series of radar reflectivity at $250 \mathrm{~m}$ altitude (left) and VIPWC (right) from 2318 LST to 2348 LST on 28 January. Convective cells recognized in each time period are also marked by crosses and labeled from a to g. Arrows in the right panels show the location of the maximum vertically integrated PWC at each time. The solid lines in the left panels show the location of the vertical cross section shown in Figs. 14 (a) (c). The dashed lines in the left panels show the location of the vertical cross section shown in the left panels of Fig. 16. 
Table 1. Averaged moving speed of the local maxima of VIPWC, northeastern and southwestern edge of the isocontour of VIPWC, and convective cells in bands I and II.

\begin{tabular}{|c|c|c||c|c|}
\hline \multirow{2}{*}{} & \multicolumn{2}{|c||}{ Band I } & \multicolumn{2}{c|}{ Band II } \\
\cline { 2 - 5 } & eastward & northward & eastward & northward \\
\hline $\begin{array}{c}\text { local maxima } \\
\text { of VIPWC }\end{array}$ & $31.8 \mathrm{~m} \mathrm{~s}^{-1}$ & $5.4 \mathrm{~m} \mathrm{~s}^{-1}$ & $22.9 \mathrm{~m} \mathrm{~s}^{-1}$ & $3.1 \mathrm{~m} \mathrm{~s}^{-1}$ \\
\hline $\begin{array}{c}\text { northeastern } \\
\text { edge of the } \\
\text { isocontour }\end{array}$ & $33.4 \mathrm{~m} \mathrm{~s}^{-1}$ & $6.0 \mathrm{~m} \mathrm{~s}^{-1}$ & $31.5 \mathrm{~m} \mathrm{~s}^{-1}$ & $6.5 \mathrm{~m} \mathrm{~s}^{-1}$ \\
\hline $\begin{array}{c}\text { southwestern } \\
\text { edge of the } \\
\text { isocontour }\end{array}$ & $24.0 \mathrm{~m} \mathrm{~s}^{-1}$ & $2.7 \mathrm{~m} \mathrm{~s}^{-1}$ & $17.6 \mathrm{~m} \mathrm{~s}^{-1}$ & $-4.5 \mathrm{~m} \mathrm{~s}^{-1}$ \\
\hline $\begin{array}{c}\text { convective } \\
\text { cells in the } \\
\text { band }\end{array}$ & $19.1 \mathrm{~m} \mathrm{~s}^{-1}$ & $0.5 \mathrm{~m} \mathrm{~s}^{-1}$ & $18.9 \mathrm{~m} \mathrm{~s}^{-1}$ & $2.0 \mathrm{~m} \mathrm{~s}^{-1}$ \\
\hline
\end{tabular}

show the structure of a mesoscale convergence line.

\subsection{Detection of a mesoscale convergence line}

A mesoscale convergence line along the coast of Hokuriku district was identified in previous studies by analyzing AMeDAS data or data taken by upper-air soundings. However, such data was too coarse to investigate the spatial structure of the convergence line and its temporal change in detail. Thus, we used Doppler radar data to examine the horizontal and ver- tical structure of the convergence line. Figure 10 shows the along-band $\left(u^{\prime}\right)$ and band-normal $\left(v^{\prime}\right)$ components of the horizontal wind field derived from dual-Doppler radar data (Kashiwazaki and Joetsu). The $x^{\prime}$-averaged value of each component is shown in the right panel of Fig. 10.

The across-band component $\left(v^{\prime}\right)$ showed remarkable differences between the offshore side $\left(-15 \sim-13 \mathrm{~m} \mathrm{~s}^{-1}\right)$ and the inshore side $\left(-1 \sim 1 \mathrm{~m} \mathrm{~s}^{-1}\right)$, indicating a strong convergence (about $-2.5 \times 10^{-3} \mathrm{~s}^{-1}$ in maximum). In con-
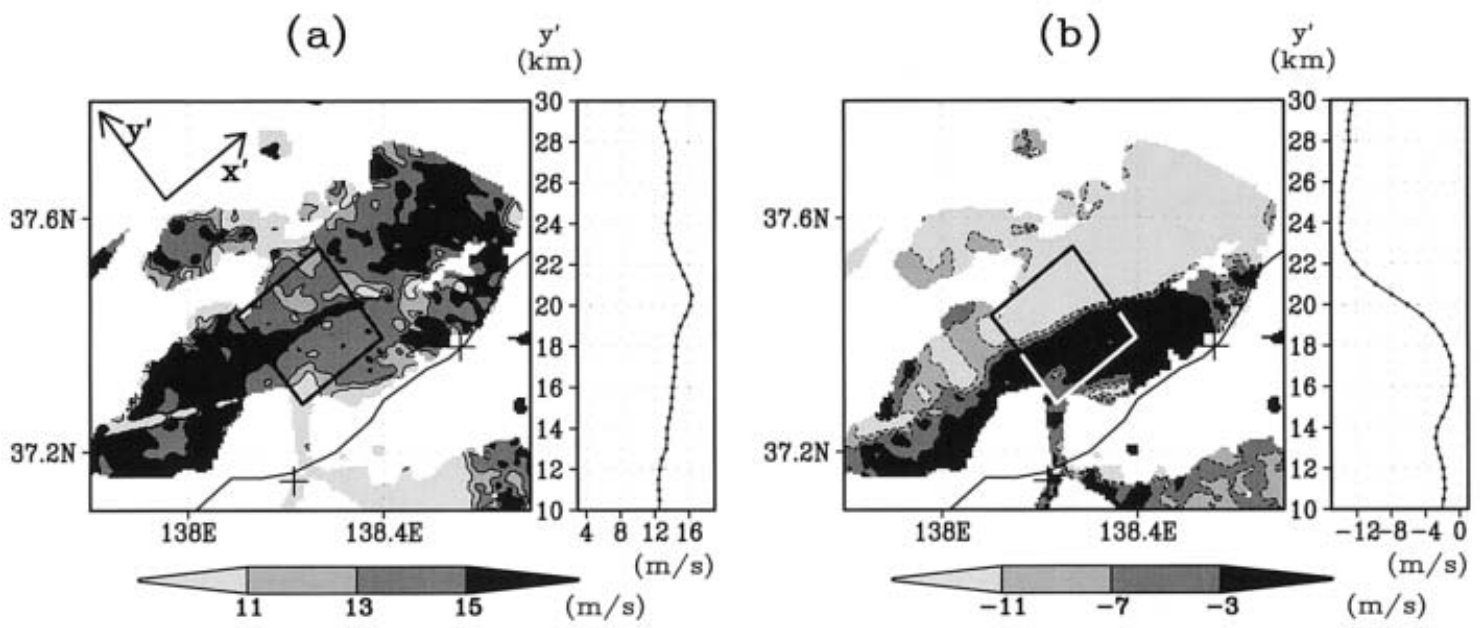

Fig. 10. Horizontal distribution of (a) band-parallel $\left(u^{\prime}\right)$ and (b) band-normal components $\left(v^{\prime}\right)$ of the horizontal wind at the $250 \mathrm{~m}$ altitude at 2330 LST on 28 January. Variations of each component in the $y^{\prime}$ direction are calculated by taking $x^{\prime}$-average within the square and shown in the right. 

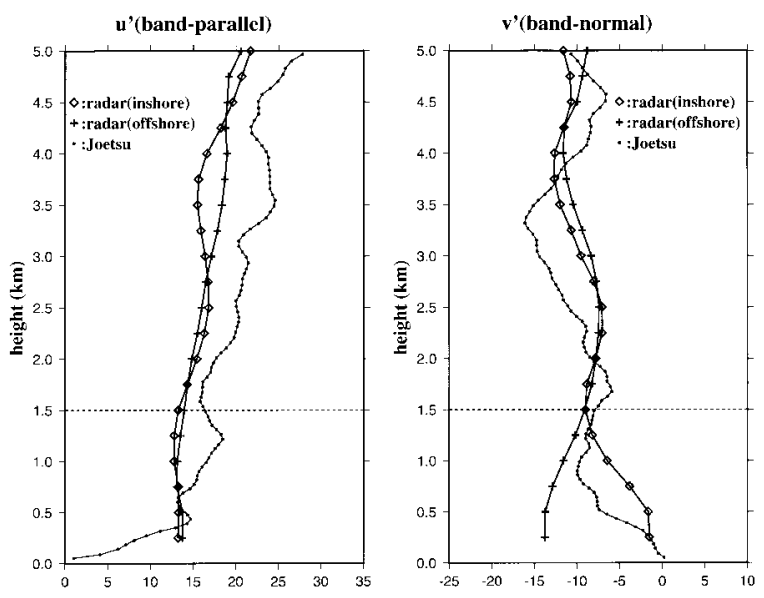

Fig. 11. Vertical profiles of band-parallel $\left(u^{\prime}\right)$ and band-normal components $\left(v^{\prime}\right)$ of horizontal wind averaged on the offshore (+) and the inshore ( $\square$ ) sides at 2330 LST on 28 January. Vertical profiles of each by sounding data of Joetsu (•) at 21 LST on 28 January are also shown for comparison.

trast, the along-band component $u^{\prime}$ on the offshore side is almost the same as that in the inshore side of the convergence line, indicating the absence of substantial wind shear across the convergence line. The larger $u^{\prime}$ values in the vicinity of the convergence line than those in other areas were probably due to the confluence of westerly and southwesterly winds.

Mean vertical profiles of $u^{\prime}$ and $v^{\prime}$ on the offshore and inshore sides of the convergence line are shown in Fig. 11. Profiles of $v^{\prime}$ show remarkable differences between the inshore side and the offshore side below $\sim 1.5 \mathrm{~km}$. On the offshore side, both the along-band and acrossband components of the horizontal wind were strong, which means that a strong westerly prevailed on the offshore side. In contrast, the across-band component was rather small compared with the along-band component below $1.5 \mathrm{~km}$ on the inshore side, indicating that a southwesterly prevailed there. These wind profiles indicate that the convergence line along the coast was formed at the interface of the offshore westerly and the $1 \mathrm{~km}$-deep low-level southwesterly along the coast. We will discuss the formation mechanism of the mesoscale convergence line in section 5.1.

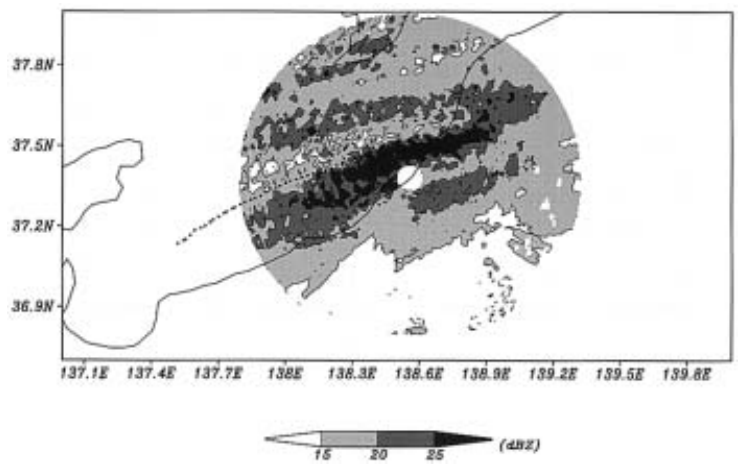

Fig. 12. Time averaged radar reflectivity measured at the Kashiwazaki radar at the $2 \mathrm{~km}$ altitude from $2230 \mathrm{LST}$ on 28 January to 0118 LST on 29 January. The dotted line shows the averaged position of the low-level convergence line of wind derived from the Doppler radar data.

Figure 12 shows the time-averaged radar reflectivity of the Kashiwazaki radar at the $2 \mathrm{~km}$ altitude during the passage of the snowbands (from 2230 LST on 28 January to 0118 LST on 29 January). The time-averaged position of the convergence line is indicated by a dotted line. The time-averaged radar reflectivity showed larger values along the inland side of the convergence line. Figure 12 also indicate a secondary peak of reflectivity in the lee side of Noto Peninsula. Some researchers (Miyazawa 1968; NLMO) also noted the formation of such radar echoes in the lee side of Noto Peninsula. This secondary peak of radar reflectivity will not be further investigated in this paper, because the wind fields in this area were not well derived by the Doppler observations.

The accumulated snowfall amount measured by AMeDAS (Fig. 13) shows that the snowfall was actually large in the leeward of the convergence line $\left(139 \sim 139.8^{\circ} \mathrm{E}\right.$ and $37.4 \sim$ $37.8^{\circ} \mathrm{N}$ ). It should be noted here that the distribution of snowfall amount is similar to that of the plain-type snowfall reported by Akiyama (1981a).

\subsection{Temporal change of radar echo and dynamic structures of convective cells near the convergence line}

Figure 14 shows vertical cross sections of radar reflectivity, the vertical velocity $w$, and 


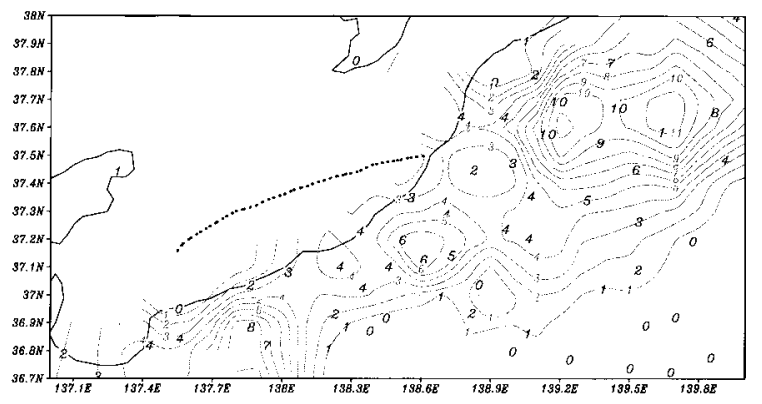

Fig. 13. Accumulated snowfall amount of AMeDAS data from 2230 LST on 28 January to 0230 LST on 29 Jan. Here, rainfall data was used by converting the rainfall amount of $1 \mathrm{~mm}$ to the accumulated snowfall amount of $1 \mathrm{~cm}$. Location of the averaged position of the low-level convergence line is also shown as in Fig. 10.

the system-relative velocity $v^{\prime}$ along the line shown in Fig. 9. Each section crosses cell e and depicts the evolution process of band I. Before the development of band I (Fig. 14a), the lowlevel convergence and an updraft existed at $y^{\prime}=32 \sim 36 \mathrm{~km}$. The axis of maximum updraft was slightly tilted toward the offshore side. Other bands also showed the same structure as band I (not shown). At 2330 LST, when band I began to develop, a frontal surface of low-level southwesterly wind was located at $y^{\prime}=20 \mathrm{~km}$ and a strong updraft extended up to $6 \sim 7 \mathrm{~km}$. Radar reflectivity in the updraft also became strong, especially at an altitude of about $4 \mathrm{~km}$. This indicates that the strong updraft sustained large precipitation particles. By 2336 LST, the updraft became weak and tilted toward the land (Fig. 14c). The front of low-level southwesterly wind retreated and its depth became thinner than that observed at 2330 LST. The area of strong radar reflectivity ( $\geq 30 \mathrm{dBZ}$ ) descended and became wider compared with that seen at 2330 LST. We will discuss the temporal change of the vertical orientation of the updraft and the corresponding development of convective cells in section 5.2.

We then investigated the temporal change of the horizontal and vertical structures of the low-level southwesterly wind associated with the approach and evolution of convective cells.
Figure 15 shows the temporal change of the radar reflectivity pattern at an altitude of $2 \mathrm{~km}$, and horizontal wind vector and wind direction at the lowest altitude $(250 \mathrm{~m})$, from $2318 \mathrm{LST}$ on 28 January to 0018 LST on 29 January, 2001. As shown in the right panels of Fig. 15, the wind shift zone retreated toward the coast and became vague over the period from 2318 to 2342 LST. After band I landed, however, a southwesterly wind appeared again over the sea and the wind shift zone was reestablished around $138^{\circ} \mathrm{E}$ and $37.3^{\circ} \mathrm{N}$ by $0006 \mathrm{LST}$.

Figure 16 shows the vertical cross sections of the radar reflectivity and $v^{\prime}$ at $x^{\prime}=$ $-40.0 \mathrm{~km}$. During the observation period, the snowbands moved at a speed of $-6.9 \mathrm{~m} \mathrm{~s}^{-1}$ in the $y$-direction. Thus the contour line of $v^{\prime}=-6.9 \mathrm{~m} \mathrm{~s}^{-1}$, which indicates the outline of the band-relative southwesterly inflow, is also shown by a bold line. As shown in Fig. 16, the edge of the surface front of the southwesterly wind layer retreated toward the coast associated with the passage of band I from 2318 to 2330 LST. The southwesterly wind layer became thinner (from $1.0 \sim 1.3 \mathrm{~km}$ at $2318 \mathrm{LST}$ to $0.7 \sim 0.8 \mathrm{~km}$ at $2336 \mathrm{LST}$ ) associated with the development and passage of convective cells. The southwesterly airflow then advanced again, and formed another convergence line from 0006 to 0012 LST at almost the same location as before.

The convergence line was formed again before the passage of band III (0100 LST). However, the low-level southwesterly layer was rather thin $(0.5 \sim 0.7 \mathrm{~km})$ compared with previous ones, and the convergence line was located about $10 \mathrm{~km}$ further inshore.

Since the kinematic structure of the convergence line was not obtained when the snowbands are far apart from it, it is difficult to fully capture the reestablishment process of lowlevel convergence line. In the next section, the role of the convergence line on the evolution of snowbands are discussed. It should be mentioned, however, that the decaying snowbands and/or approaching snowbands themselves may possibly contribute to the reestablishment of the convergence line. As shown later, the sublimation of snow particles from the decaying snowbands occurred in the southwesterly layer, which probably facilitated the reestablishment of the convergence zone. 
(a)
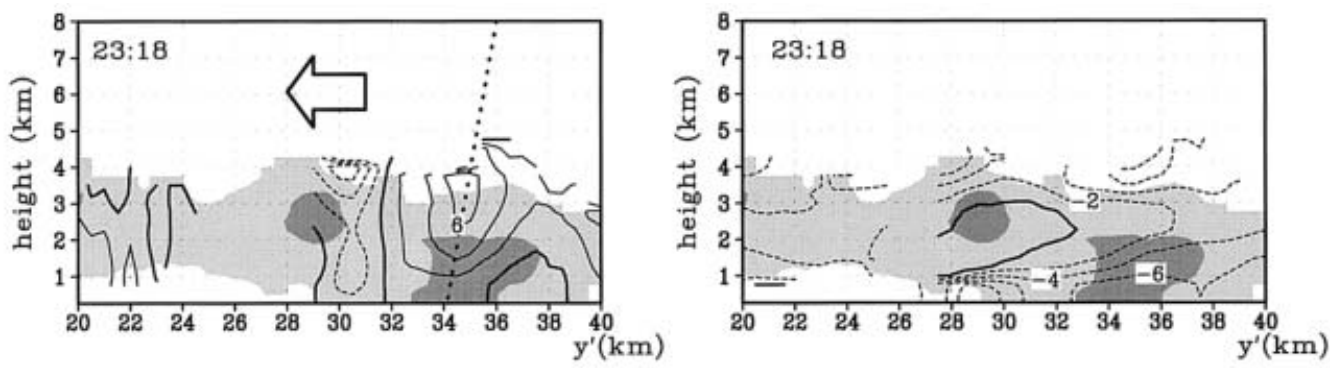

(b)
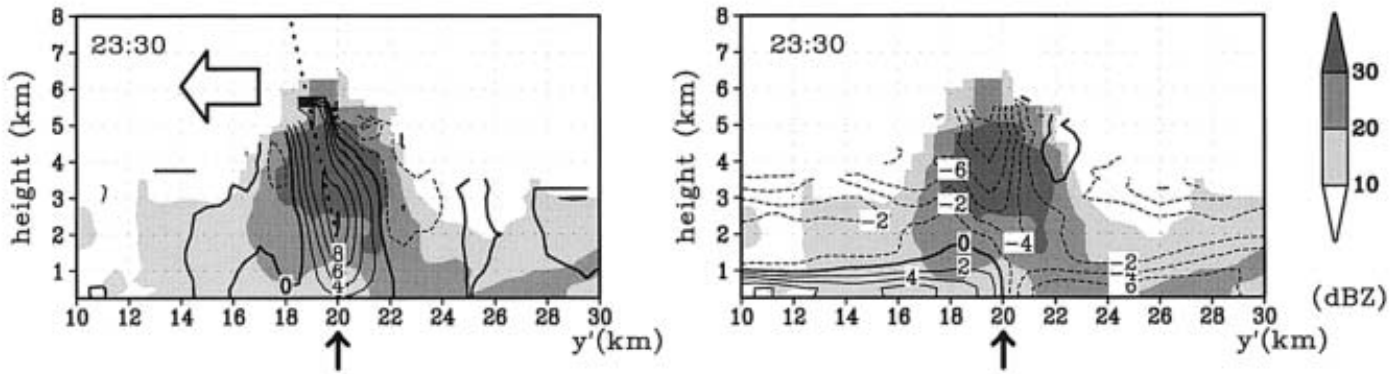

(c)
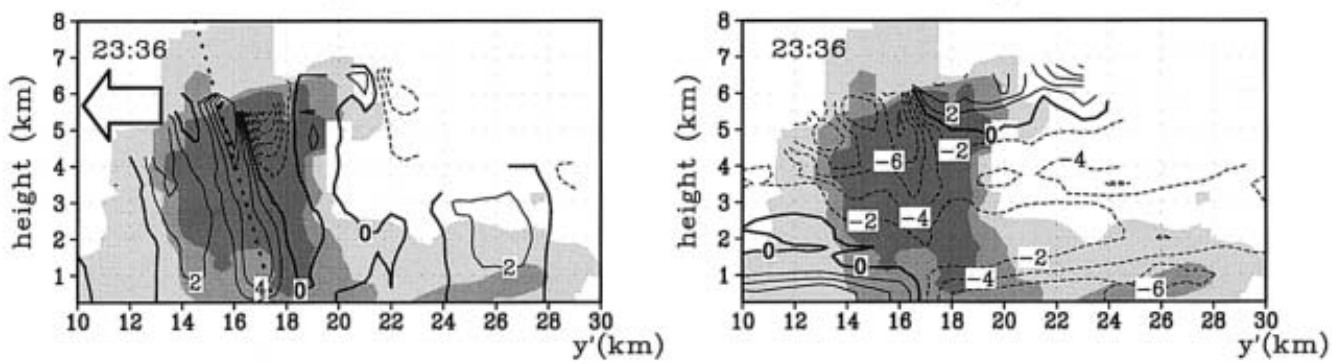

Fig. 14. Vertical cross sections of the radar reflectivity and the contour of the vertical wind velocity $w$ (left) and the system relative velocity of the band-normal component $v^{\prime}$ (right) along the lines shown in Fig. 9. Open arrows in the left panels show the direction of echo movement. Bold arrows show the location of the edge of the southwesterly.

\section{Discussion}

\subsection{Origin of the low-level southwesterly wind responsible for the formation of the convergence line}

The convergence line detected by the Doppler radars extended from the east of Toyama Bay to the north of Kashiwazaki. To discuss the origin of the southwesterly wind, we analyzed the ten-minutely AMeDAS data at stations along the coast of Hokuriku district (Fig. 17). Figure 18 shows the temporal change of surface winds and GMS $T_{B B}$ from 09 LST on 28 January to 09 LST on 29 January at each station (station $5 \sim 19)$. The low $T_{B B}$ from 18 LST on 28 January to 03 LST on 29 January corresponds to the passage of the frontal cloud band. The average surface air temperature began to drop when the frontal cloud arrived at the AMeDAS sites (18 LST on 28 January), and dropped again because of the following cold air outbreak (03 LST on 29 January).

The wind field in the western part of Noto Peninsula (stations 5 to 10, area (i)) generally represented the synoptic-scale winds; strong westerly dominated during the passage of the frontal cloud band, whereas strong northwesterly winds dominated during the outbreak of the cold air. On the other hand, weak southwesterly winds always prevailed at stations along Toyama Bay (stations 11 to 15, area (ii)). Weak southwesterly or west-southwesterly winds prevailed further east of Toyama Bay (stations 16 to 19, area (iii)) during the passage of the frontal cloud band, while northwesterly winds dominated there after the frontal 

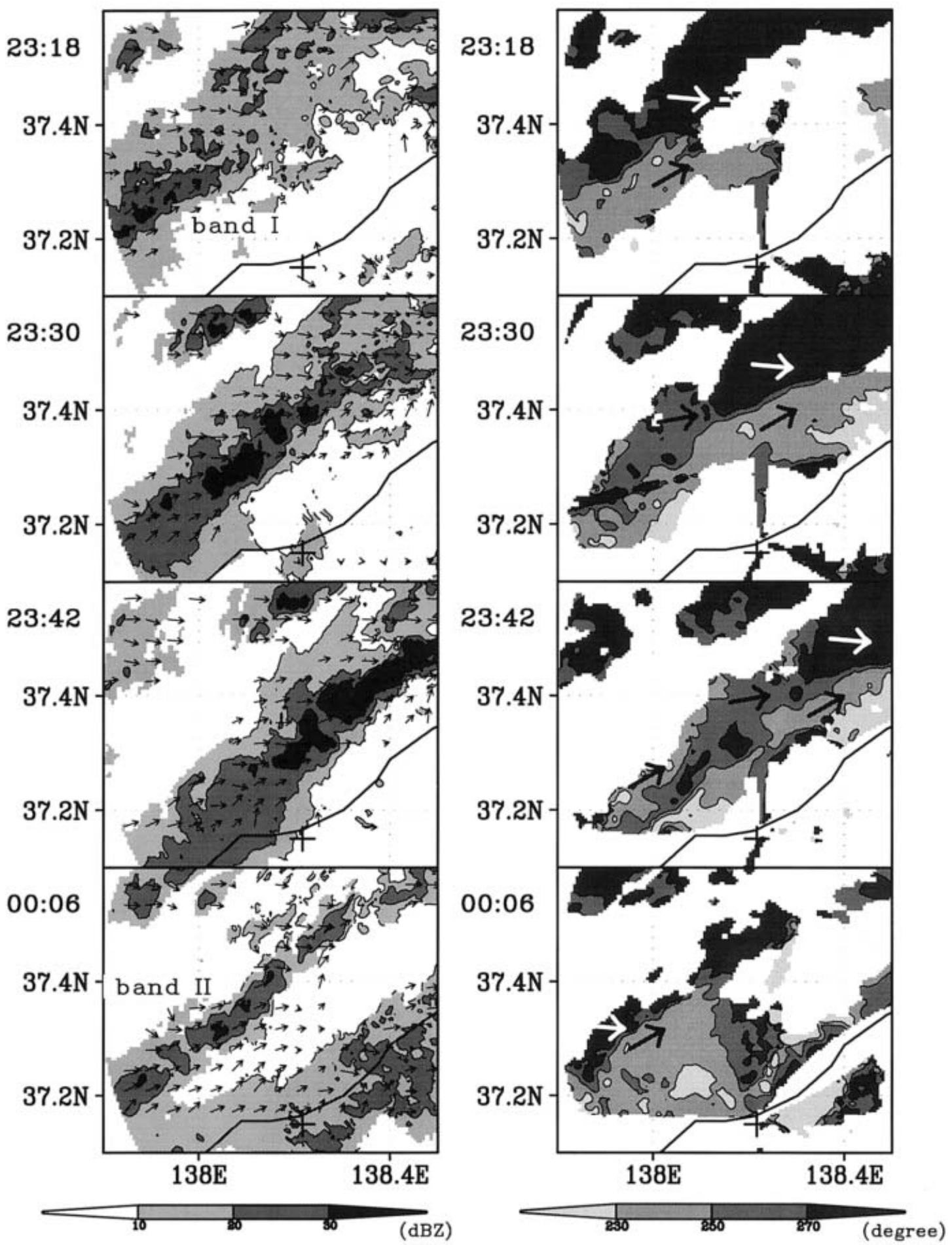

Fig. 15. Time series of the radar reflectivity at the $2 \mathrm{~km}$ altitude with the wind vector at $250 \mathrm{~m}$ (left) and the wind direction at $250 \mathrm{~m}$ (right) from 2318 LST on 28 January to 0006 LST on 29 January. Arrows in the right panels show the prevailing wind direction in each shaded area. 

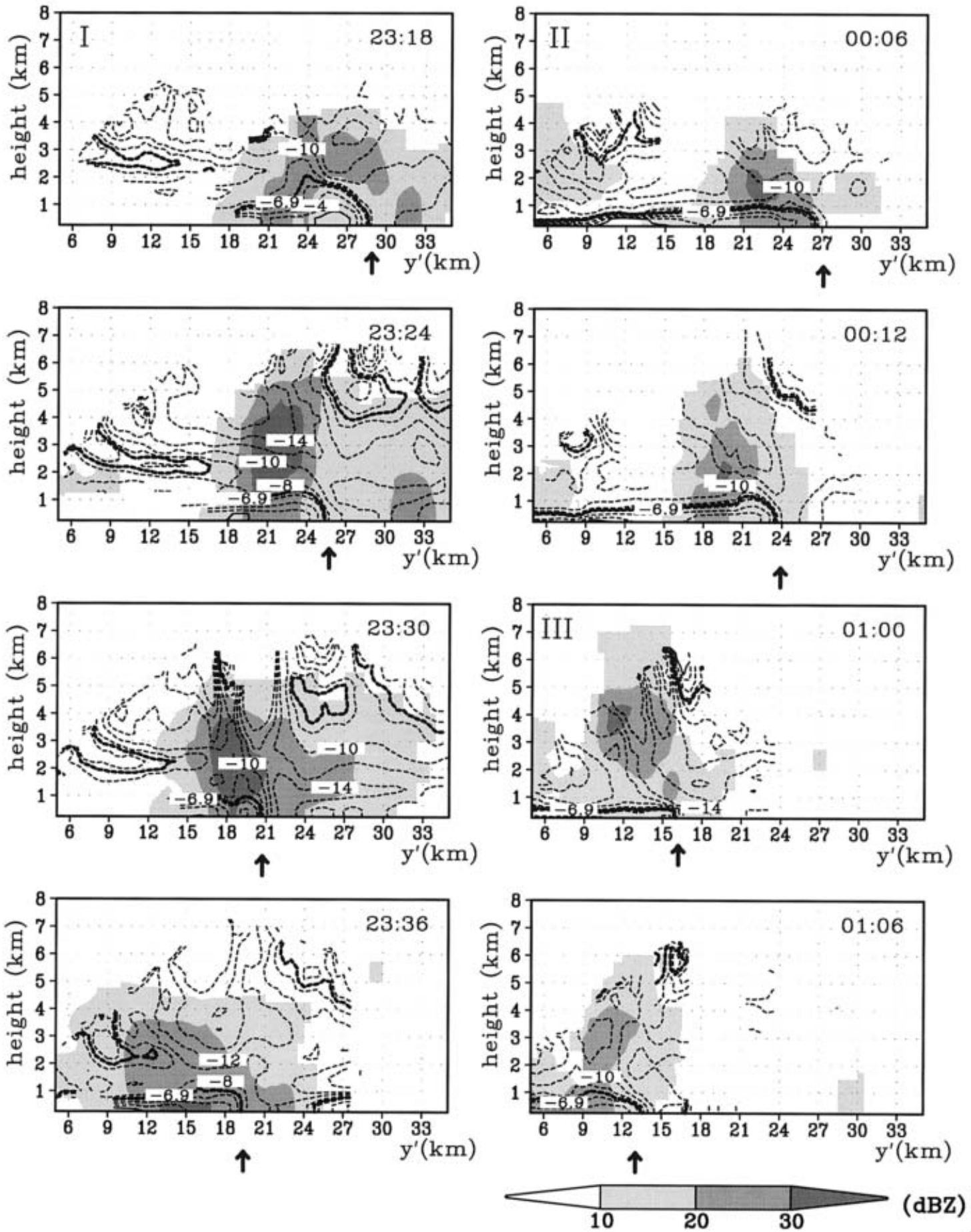

Fig. 16. Time variation of the radar reflectivity with the contour lines of $v^{\prime}$ along the line $x^{\prime}=-40.0 \mathrm{~km} . v^{\prime}$ is contoured at $2 \mathrm{~m} \mathrm{~s}^{-1}$ intervals. The location of the vertical cross section for band $\mathrm{I}$ is shown in Fig. 9. The contour of $v^{\prime}=-6.9 \mathrm{~m} \mathrm{~s}^{-1}$, which is representative of the low-level southwesterly surface, is shown by the bold line. 2318 2336 LST on 28 January, 0006 0012 LST and 0100 0106 LST on 29 January correspond to the passages of band I, II and III, respectively. The arrows show the location of the edge of the southwesterly. 


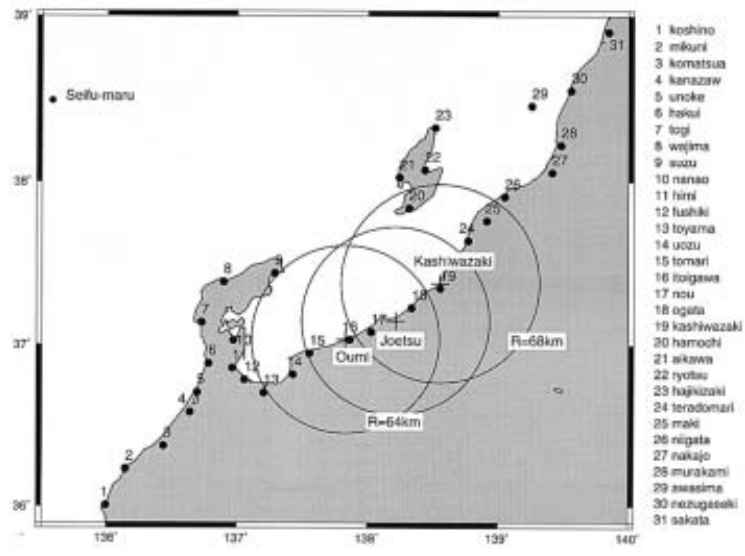

Fig. 17. Locations of the AMeDAS points along the coast of Hokuriku district. The location of Seifu-maru and the observational range of the Doppler radars are also shown. passage. In short, southwesterly or westsouthwesterly winds blew along the coast of Toyama Bay and its northeast side during the frontal passage.

To examine whether such a wind filed is typical in this region or not, we investigated the frequency distribution of wind direction during the WMO-01 IOP (from 13 to 31 January). One station was chosen in each area: (i) Togi (7), (ii) Toyama (13) and (iii) Kashiwazaki (19). Figure 19 shows the frequency distribution of the wind direction observed at these points. Winds observed at Seifu-maru, which is located windward of these sites, were considered to be affected little by orography and therefore representing the synoptic-scale winds. Thus the frequency distribution at each site is divided into two according to the wind directions (i)

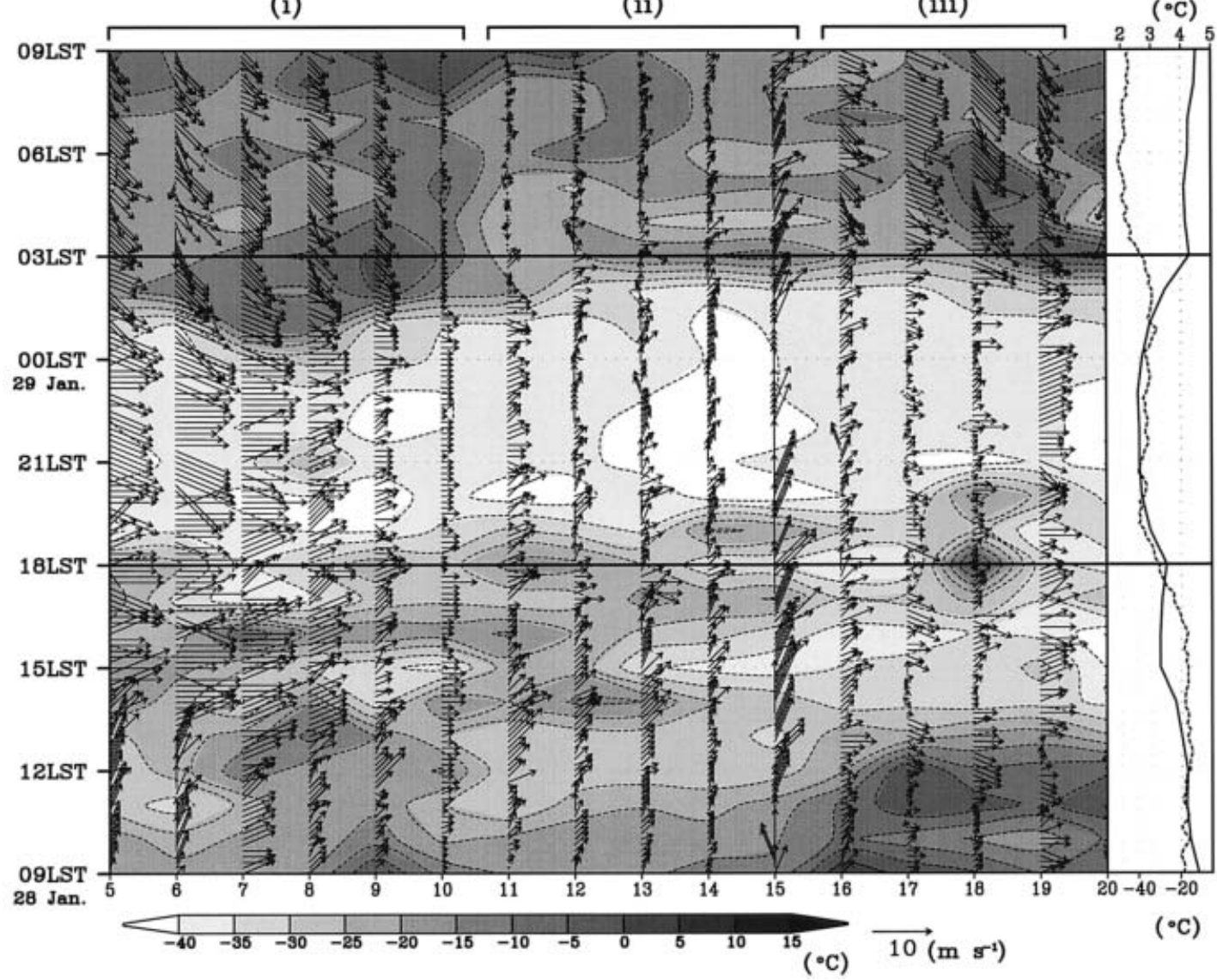

Fig. 18. Time variation of GMS $T_{B B}$ (grayscale) and surface winds (vector) at each AMeDAS point. Numbers in the abscissa show the location number of each point shown in Fig. 17. The time changes of the 31 points average of $T_{B B}$ (solid line) and temperature (dashed line) are shown in the right. The time period between the two bold lines corresponds to the period of frontal passage. 


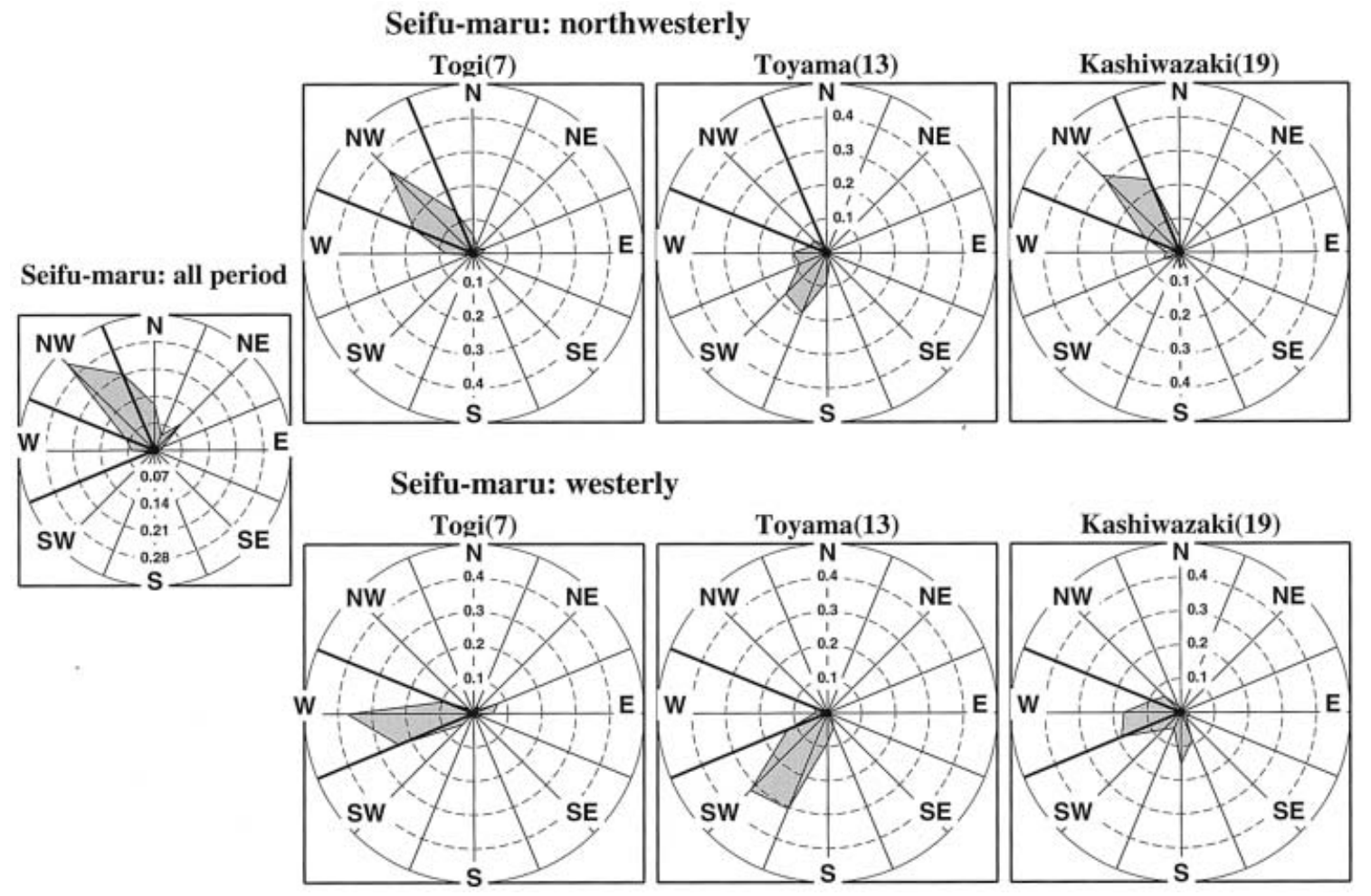

Fig. 19. Frequency distribution of the wind direction observed at three AMeDAS points, Togi (left), Toyama (center) and Kashiwazaki (right) during the WMO-01 observation are shown both when the wind direction at Seifu-maru $(\theta)$ is northwesterly $(292.5 \leq \theta \leq 337.5$, upper) and westerly (247.5 $\leq \theta \leq 292.5$, lower). Also shown in the left are the values observed at Seifu-maru.

observed at Seifu-maru. Figure 19 indicates that the wind directions observed at Togi are generally the same as those observed at Seifumaru. On the other hand, prevailing wind at Toyama was south-southwesterly or southwesterly when northwesterly and westerly winds blew at Seifu-maru. At Kashiwazaki, west-southwesterly or southerly wind prevails when the wind direction at Seifu-maru is westerly. These results demonstrate that the wind fields shown in Fig. 18 are not unusual ones, at least during the WMO-01 IOP. Thus it is suggested that the wind fields in areas (ii) and (iii) are considerably influenced by topography in this region.

The existence of a convergence line has been reported by many authors (e.g., Funada 1993; NLMO; Ookubo and Kurokawa 2000) and a similar mesoscale convergence line was also observed during another period of WMO-01 (Kusunoki et al. 2002). Eito et al. (2003) suc- cessfully simulated such wind fields by using a non-hydrostatic numerical model (MRI/NPDNHM).

Time variations of temperature at $15 \mathrm{AMe}-$ DAS stations (station 5 19) are shown in Fig. 20 . Note that the temperature scale shows the deviation from the average over the 31 stations shown in Fig. 17. During the passage of front, temperature deviations at stations 16 to 19 (area (iii)) were negative and the temperature difference was as large as $4 \sim 5^{\circ} \mathrm{C}$ between areas (i) and (iii). Comparison between Fig. 18 and Fig. 20 indicates that the southwesterly wind was colder than the prevailing westerly.

In addition to the dynamical effect of the topography, the thermal contrast between the westerly or northwesterly wind over the sea, and the southwesterly wind near the coast may also contribute to the formation of the sharp convergence line. As the airflow deflects from westerly to southwesterly over the land, it will 
(i)

(ii)

(iii)

$\left({ }^{\circ} \mathrm{C}\right)$

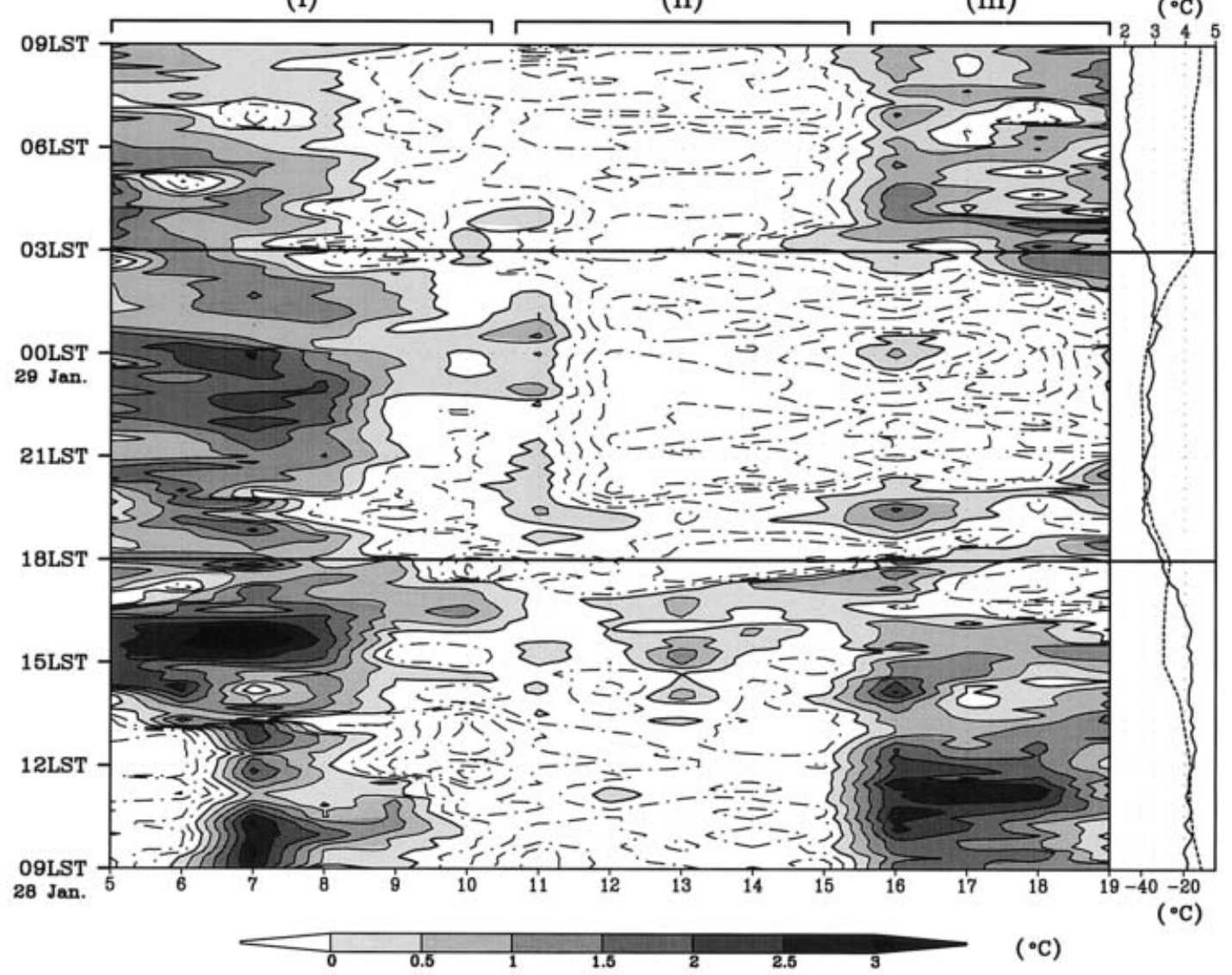

Fig. 20. Same as Fig. 18, but for the temperature deviations from the 31 points average.

be cooled by mixing with the cold air over the land. Further, as the relative humidity was relatively low in the layer from 500 to $800 \mathrm{~m}$ (Fig. 4), the sublimation of snow particles may also play an important role in maintaining the sharp convergence line as indicated by Eito et al. (2003). In fact, radar reflectivity in Fig. 16 shows that precipitation particles actually fell into the low-level southwesterly wind region. Further, the time-averaged radar reflectivity shown in Fig. 21 shows that the radar echo intensity was very weak below $1 \mathrm{~km}$ between $37.1^{\circ} \mathrm{N}$ and $37.2^{\circ} \mathrm{N}$. These results suggest that the sublimation of snow particles occurred in the southwesterly wind region.

\subsection{Physical process of the evolution of snowbands}

Next, we will discuss why convective cells within the snowbands developed at the front of the low-level southwesterly airflow.
The Doppler radar-derived wind fields revealed the strong convergence of $\sim 10^{-3} \mathrm{~s}^{-1}$ at the northern edge of the southwesterly airflow. As indicated by Eito et al. (2003), such a strong low-level convergence might cause convective cells in the bands. However, the situation we consider here is different from that investigated by Eito et al. (2003), in that the snowbands convective cells investigated in our study are not persistently attached to the low-level convergence zone. Thus it is suggested that in addition to the effect of low-level convergence, there could be other factors that cause the intensification of convection in the snowbands.

As seen in Fig. 14a, convective cells within the band tilted toward the offshore (rearward) side before they encountered the convergence line. Generally, the axis of the updraft tilts toward the downshear side in the absence of other external forcing such as low-level cold pool circulations. Figure 22 shows vertical pro- 


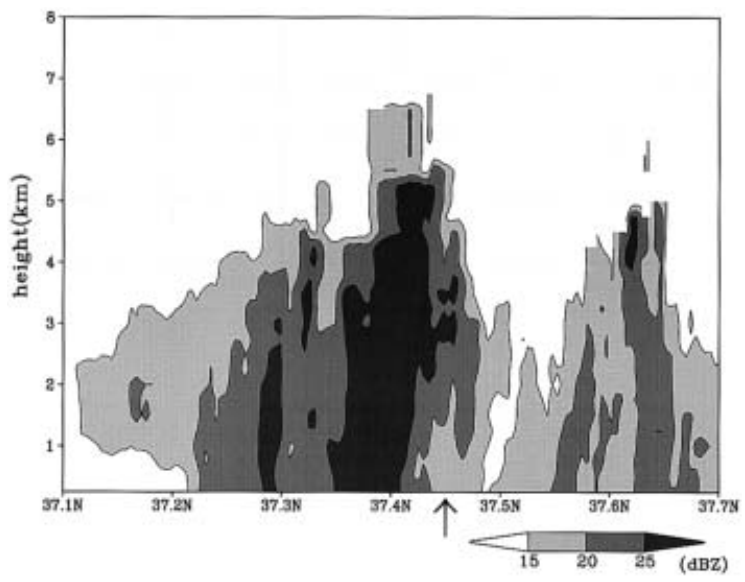

Fig. 21. Vertical cross section of the time averaged radar reflectivity observed by the Kashiwazaki radar from 2330 LST on 28 January to 0118 LST on 29 January at $138.3^{\circ} \mathrm{E}$. The bold arrow shows the averaged position of the convergence line derived from the Doppler radar data.

files of environmental along-band wind $u^{\prime}$ and across-band wind $v^{\prime}$ during the passage of the snowbands. When the snowband was located well off the coast, the axis of convective updraft was tilted toward the offshore side. This is probably because the vertical profile of $v^{\prime}$ shows positive shear $\left(\frac{\partial v^{\prime}}{\partial z}>0\right)$ below an altitude of $1.8 \mathrm{~km}$. However, the axis of convective updrafts stood almost upright or slanted slightly toward the coast (front) when they encountered the convergence line (Figs. 14b and c).

The temperature gradient across the convergence line revealed by AMeDAS and radiosonde data suggests the presence of a baroclinically-induced $x^{\prime}$-component vorticity $\eta^{\prime}\left(\eta^{\prime}>0\right)$ at the edge of the low-level southwesterly airflow, where contours of wind speed show the characteristics of typical density current. On the other hand, the vertical profile of the environmental low-level wind showed negative horizontal vorticity $\left(\eta^{\prime}<0\right)$, as shown in Fig. 22. The balance of such conflicting vorticities is known to greatly influence the tilt of convective updrafts (Rotunno et al. 1988; hereafter RKW). The updraft of a convective cell would stand upright if these two vortices balanced, otherwise it would slant because of the

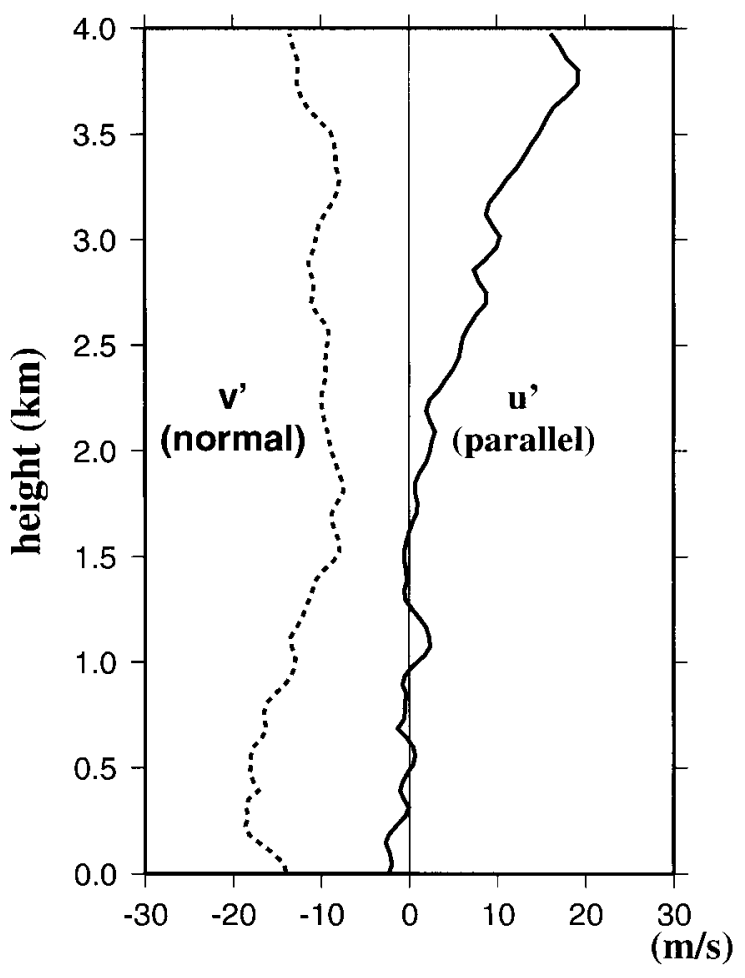

Fig. 22. Vertical profiles of the bandparallel $\left(u^{\prime}\right.$, solid line) and the bandnormal $\left(v^{\prime}\right.$, dashed line) wind components derived from the sounding data at Seifu-maru at 00 LST on 29 January.

effect of the stronger vorticity. Therefore, it is suggested that convective cells in the band became upright and subsequently slanted toward inland because of the effect of baroclinicallyinduced horizontal vorticity at the edge of the low-level southwesterly. The situation we consider here is different from that investigated by RKW in that the convective updrafts are not persistently attached to the leading edge of the cold air. Nevertheless, it would be helpful to evaluate the vorticity balance at the leading edge of the cold southwesterly in a similar way as RKW, to facilitate our understanding of the temporal behavior of convective updrafts.

According to RKW, the balance can be evaluated by comparing two parameters $C$ and $\Delta u$, where $C$ represents the cold-pool strength and $\Delta u$ represents the velocity difference over the depth of the cold pool in the ambient air ahead of the cold pool. The parameter $C$ can be given by $C=\sqrt{g h \Delta \theta_{v} / \theta_{v}}$, where $g$ is the gravitational 
acceleration, $h$ the depth of the cold air, $\Delta \theta_{v}$ the difference in virtual potential temperature across the leading edge, and $\theta_{v}$ the virtual potential temperature in the cold air. Although it is difficult to properly estimate the virtual potential temperature change across the leading edge of the cold southwesterly, the AMeDAS data shown in Fig. 20 suggests that it would be about $4 \sim 5 \mathrm{~K}$. The values $h \sim 1 \mathrm{~km}, \Delta \theta_{v} \sim 4 \mathrm{~K}$, and $\theta_{v} \sim 275 \mathrm{~K}$ gives $C \sim 12 \mathrm{~m} \mathrm{~s}^{-1}$. On the other hand, the band-normal wind profile in the offshore side of the convergence line shown in Fig. 22 indicates $\Delta u$ over the lowest $1 \mathrm{~km}$ would be $5 \mathrm{~m} \mathrm{~s}^{-1}$ at most. These estimates indicate that the condition at the leading edge of the cold southwesterly is such that $C \gg \Delta u$, suggesting that the downshear tilted convective updrafts would lean toward the inland when they encountered the leading edge of the cold southwesterly.

In their Doppler radar study on the snowbands that developed along the west coast of Hokkaido, Japan, Tsuboki et al. (1989a) pointed out that the movement of the land breeze front was controlled by the balance between the supply of cold air from land and the entrainment of land-breeze air into the northwesterly monsoon. They also suggested that the land-breeze front would advance toward the offshore if the former prevailed, as was the case in Tsuboki et al. (1989b), otherwise it would retreat toward the inland as was the case in Fujiyoshi et al. (1988).

In our case, the depth of the low-level southwesterly layer showed significant time variations and the location of the convergence line showed significant oscillation associated with the evolution of snowbands. This is probably because the snowbands in the present study are rather tall $(6 \sim 7 \mathrm{~km}$ in maximum) and strong compared with those analyzed in the aforementioned studies (2 3 $\mathrm{km}$ at most), and therefore the snowbands themselves significantly affect the structure and behavior of the low-level southwesterly layer and the convergence line.

While the surface front was being driven toward the coast, low-level southwesterly air was consumed by the developing convective cells and the frontal surface of the southwesterly became indistinct. The snowbands make an angle of about $20^{\circ}$ to the orientation of front and they encountered the front from their southwestern side. Thus the destruction of the frontal surface of the southwesterly occurred gradually from its southwestern side. After the passage of the snowband, the advection of the southwesterly was able to reestablish the southwesterly front prior to the approach of the following snowband. Further, it was also suggested that sublimation of snow particles in the southwesterly layer was helpful to the reestablishment of the front.

Ishihara et al. (1989) investigated the structure of the snowbands that developed between the winter monsoon and a land breeze in the western Hokuriku district. They also pointed out that the pumping of land breeze air into the updraft of the snowbands caused the land breeze to retreat, while the dissipation of snowbands allowed the front to advance offshore again. The results of our study and Ishihara et al. (1989) suggests that the snowbands and low-level convergence lines show strong interactions along the coastal region of Hokuriku area, where snowbands are rather strong compared with those develop in the other coastal region of Sea of Japan.

\section{Conclusions}

During the WMO-01 observations, several snowbands associated with a cold front developed remarkably at $10 \sim 30 \mathrm{~km}$ off the coast of Hokuriku district on 28 and 29 January 2001. In this paper, Dual-Doppler radar analysis was made to investigate the mechanisms responsible for the successive development of the snowbands. Three snowbands were observed in the strong westerly wind field with the pressure pattern typical of plain-type snowfalls. When they were well offshore, the snowbands were composed of weak convective cells with heights of about $4 \mathrm{~km}$ and their radar reflectivity was weaker than $30 \mathrm{dBZ}$. As they approached the coast, the convective cells in the bands extended upward to $6 \sim 7 \mathrm{~km}$ (almost reaching the tropopause altitude) and the radar reflectivity in them became stronger than $40 \mathrm{dBZ}$. After the landing, the convective cells became weak and acquired stratiform features.

The analysis of Doppler-derived wind fields revealed a convergence line between the prevailing westerly and the low-level southwesterly $10 \sim 30 \mathrm{~km}$ offshore, where the bands 


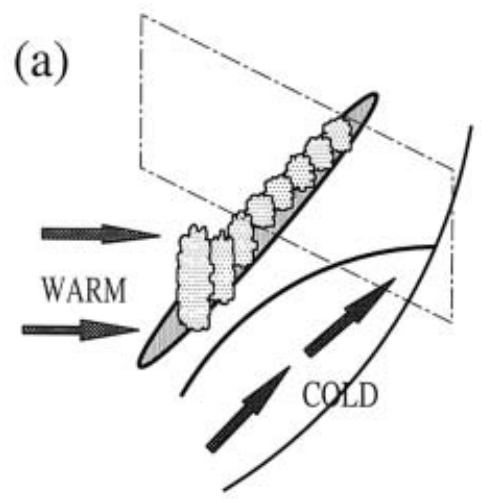

(b)
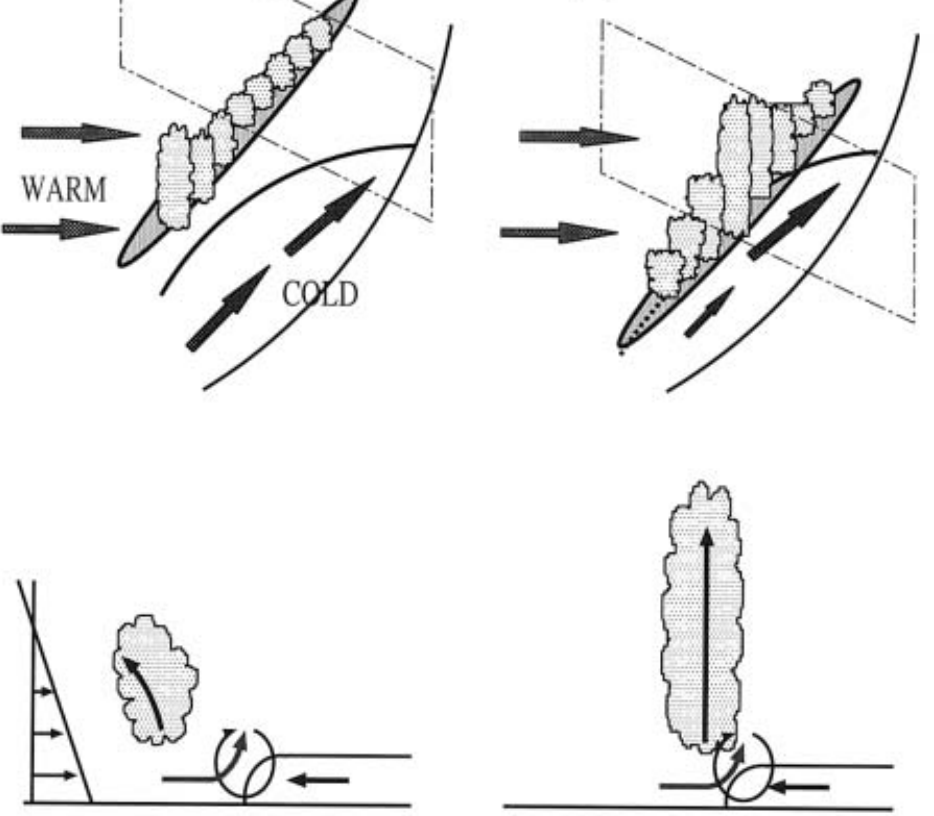

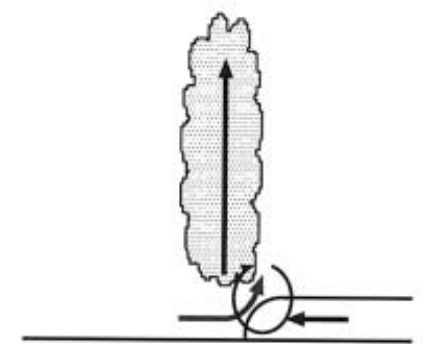

(c)
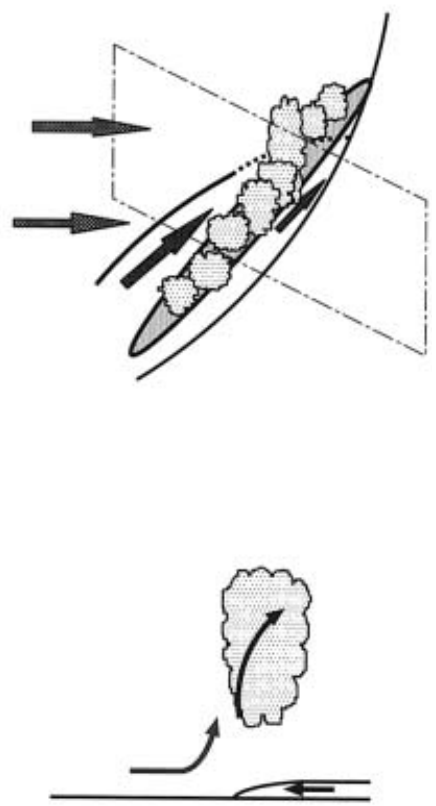

Fig. 23. Schematic description of the evolution of snowbands and the convergence line. The lower figures depict the vertical cross section shown by the rectangles in the upper figures.

showed abrupt enhancement. The low-level southwesterly along the coast is suggested to be the result of the orographic modification of the prevailing westerly, and was about $4 \sim 5^{\circ} \mathrm{C}$ colder than the prevailing westerly.

The essence of the successive development of the snowbands, as revealed in this study, is schematically shown in Fig. 23.

(a) A low-level cold southwesterly was formed near the coast, which resulted in the formation of the mesoscale convergence line between the prevailing westerly. When a snowband associated with a cold front was well off the coast, convective cells in the band slanted toward offshore, because of the effect of vertical wind shear of the prevailing westerly wind.

(b) As the snowband approached the convergence line, convective cells in the band became upright because of the baroclinically induced horizontal vorticity at the edge of the low-level southwesterly, and active convective cells developed successively from the southwestern part of the band. Meanwhile, the low-level southwesterly was consumed by the active convective cells, and the surface front retreated to- ward the inland. The convergence line becomes indistinct from the southwestern side.

(c) The convective cells in the band subsequently leaned toward the inland and weakened. After the passage of the band, advection of the southwesterly made the southwesterly layer thicker, which reestablished the convergence line, just like the one formed before the passage of the band. Thus, the following snowband was able to develop in the same way (again following $\mathrm{a} \rightarrow \mathrm{b} \rightarrow \mathrm{c}$ ).

In this study, we attempted to elucidate the interaction between the snow clouds and the convergence line. On the coastal region of Hokuriku district facing the Sea of Japan, such a convergence line frequently appears and causes heavy snowfall. This study will facilitate the understanding of the mechanisms of enhancement of snow clouds in the Hokuriku district and in the coastal region of other areas (e.g., the west coast of Hokkaido).

\section{Acknowledgements}

The authors would like to express sincere thanks to the members of WMO-01 observa- 
tion $^{1}$. We would also like to thank Sento Nakai for providing Doppler radar data and helpful comments, and two anonymous reviewers for their valuable comments. This work was supported by Core Research for Evolutional Science and Technology of Japan Science and Technology Agency.

\section{References}

Akiyama, T., 1981a: Time and spatial variations of heavy snowfalls in the Japan Sea coastal region. Part I. Principal time and space variations of precipitation described by EOF. J. Meteor. Soc. Japan, 59, 578-590.

, 1981b: Time and spatial variations of heavy snowfalls in the Japan Sea coastal region. Part II. Large-scale situations for typical spatial distributions of heavy snowfalls classified by EOF. J. Meteor. Soc. Japan, 59, 591-601.

Armijo, L., 1969: A theory for the determination of wind and precipitation velocities with Doppler radars. J. Atmos. Sci., 26, 570-573.

Braun, S.A., R.A. Houze Jr., and B.F. Smull, 1997: Airborne dual-Doppler observation of an intense frontal system approaching the Pacific northwest coast. Mon. Wea. Rev., 125, 31313156.

Eito, H., T. Kato, M. Yoshizaki, and WMO-01 Observation Group, 2003: Numerical simulation of the quasi-stationary snowband observed over

1 Masanori Yoshizaki, Kazuo Saito, Teruyuki Kato, Hisaki Eito, Takuya Kawabata, Youzou Takayama, Masato Fukuda, Ahoro Adachi, Masataka Murakami, Kenichi Kusunoki, Mizuho Hoshimoto, Naruhiro Orikasa, Yosiaki Kanno, Nobuhiko Kizu, Toshio Iguchi, Hiroshi Hanado, Shinsuke Satoh, Hiroaki Horie, Hajime Okamoto, Katsuhiro Nakagawa, Masayuki Maki, Koyuru Iwanami, Sang-Goon Park, Qoosaku Moteki, Takeshi Maesaka, Masayuki Ooi, Hiroki Fukushi, Eiko Ooishi, Noriwo Nagahama, Akira Watanabe, Hiroshi Niino, Kouji Ishikawa, Hidemoto Kanai, Yousuke Yuuki, Kazuaki Nishii, Toshio Koike, Fumiaki Kobayashi, Hiroshi Sugawara, Yousuke Ueno, Yukari Sugimoto, Kiyotaka Nakagawa, Yasushi Sakakibara, Kenji Nakamura, Haruya Minda, Atsushi Higuchi, Masafumi Hirose, Kouichi Shibakawa, Hiroshi Uyeda, Kazuhisa Tsuboki, Taro Shinoda, Sachie Kanada, Yasutaka Wakatsuki, Kouji Furukawa, Yukari Shusse, Miki Hattori, Tadayasu Ohigashi, Rei Kawabata, Tetsuya Sano, Naoko Takamatsu, Hiroyuki Hashiguchi, Mitsuhiro Teshiba, Yoshiaki Shibagaki, Zenichiro Kawasaki, Sachiko Yoshihashi, Tetsuya Kawano, Tatsuya Tanaka, Shuji Shimizu, Hideyuki Fujii, Rie Kondo, Takayuki Otsu, Toshiyuki Hara, Takafumi Amano, Motoyuki Sanada, and Toshiji Ohashi. the southern coastal area of the Sea of Japan on 16 January 2001. J. Meteor. Soc. Japan (submitted).

Funada, H., 1993: Distribution of Snowfall in Toyama Prefecture. Tenki, 40, 243-253 (in Japanese).

Fujiyoshi, Y., K. Tsuboki, H. Konishi, and G. Wakahama, 1988: Doppler radar observation of convergence band cloud formed on the west coast of Hokkaido Island (I): warm frontal type. Tenki, 35, 427-439 (in Japanese).

, K. Tsuboki, S. Satoh, and G. Wakahama, 1992: Three-dimensional radar echo structure of a snow band formed on the lee side of a mountain. J. Meteor. Soc. Japan, 70, 1124 .

, T. Endoh, T. Yamada, K. Tsuboki, Y. Tachibana, and G. Wakahama, 1990: Determination of a Z-R relationship for snowfall using a radar and high sensitivity snow gauges. J. Appl. Meteor., 29, 147-152.

Gal-Chen, T., 1982: Errors in fixed and moving frame of reference: Applications for conventional and Doppler radar analysis. J. Atmos. Sci., 39, 2279-2300.

Hane, C.E., C.J. Kessinger, and P.S. Ray, 1987: The Oklahoma squall line of 19 May 1977. Part II: Mechanisms for maintenance of the region of strong convection. J. Atmos. Sci., 44, 28662883.

Harimaya, T. and M. Sato, 1992: The riming proportion in snow particles falling on coastal areas. J. Meteor. Soc. Japan, 70, 57-65.

- $\longrightarrow$ and N. Kanemura, 1995: Comparison of the riming growth of snow particles between coastal and inland areas. J. Meteor. Soc. Japan, 73, 25-36.

Hauser, D. and P. Amayenc, 1986: Retrieval of cloud water and water vapor contents from Doppler radar data in a tropical squall line. J. Atmos. Sci., 43, 823-838.

Hsu, S.A., 1988: Coastal Meteorology. Academic Press, 260pp.

Ishihara, M., H. Sakakibara, and Z. Yanagisawa, 1989: Doppler radar analysis of the structure of mesoscale snow bands developed between the winter monsoon and the land breeze. $J$. Meteor. Soc. Japan, 67, 503-520.

Isono, K., M. Komabayasi, T. Takahashi, and T. Tanaka, 1966a: A physical study of solid precipitation from convective clouds over the sea: Part II.-Relation between ice nucleus concentration and precipitation-. J. Meteor. Soc. Japan, 44, 218-226.

,, , and T. Gonda, 1966b: A physical study of solid precipitation from convective clouds over the sea: Part IV.- 
Importance of giant sea salt nuclei in formation of solid precipitation-. J. Meteor. Soc. Japan, 44, 308-319.

Japan Meteorological Agency, 1968: Hokuriku Heavy Snowfall Report. Japan Meteorological Agency Technical Reports, 66, 481pp (in Japanese).

Kanada, S., B. Geng, N. Yoshimoto, Y. Fujiyoshi, and T. Takeda, 1999: Doppler radar observation on the orographic modification of a precipitating convective cloud in its landing. J. Meteor. Soc. Japan, 77, 135-154.

Kusunoki, K., K. Iwanami, M. Maki, S.G. Park, R. Misumi, and WMO-01 Observation Group, 2002: A dual-Doppler analysis of the mesoscale snow bands under the winter monsoon Part I: Band regeneration. Proc. International conference on mesoscale convective systems and heavy rainfall / snowfall in East Asia, 546-550.

Mizuno, H., 1992: Statistical characteristics of graupel precipitation over the Japan islands. $J$. Meteor. Soc. Japan, 70, 115-121.

Miyazawa, S., 1968: A mesoclimatological study on heavy snowfall. Pap. Meteor. Geophys., 19, 487-550.

Murakami, M., T.L. Clark, and W.D. Hall, 1994: Numerical simulations of convective snow clouds over the Sea of Japan; Two-dimensional simulations of mixed layer development and convective snow cloud formation. J. Meteor. Soc. Japan, 72, 43-62.

Niigata Local Meteorological Observatory, 1999: Study on snowbands formed around the Niigata Prefecture. Research Report of Tokyo District Meteorological Observatory, 6-32.

Ookubo, A. and Y. Kurokawa, 2000: Structure of shear line with heavy snowfall and with low visibility formed in Toyama Prefecture in a case of winter conditions. Tenki, 47, 255-266 (in Japanese).

Rotunno, R., J.B. Klemp, and M.L. Weisman, 1988: A theory for strong, long-lived squall lines. J. Atmos. Sci., 45, 463-485.

Saito, K., M. Murakami, T. Matsuo, and H. Mizuno, 1996: Sensitivity experiments on the orographic snowfall over the mountainous region of northern Japan. J. Meteor. Soc. Japan, 74, $797-813$.

Takeda, T., K. Isono, M. Wada, Y. Ishizaka, K. Okada, Y. Fujiyoshi, M. Maruyama, Y. Izawa, and K. Nagaya, 1982: Modification of convective snow-clouds in landing the Japan Sea coastal region. J. Meteor. Soc. Japan, 60, 967977.

Tsuboki, K., Y. Fujiyoshi, and G. Wakahama, 1989a: Structure of a land breeze and snowfall enhancement at the leading edge. J. Meteor. Soc. Japan, 67, 757-770.

$\longrightarrow,-$, and $\longrightarrow$ 1989b: Doppler radar observation of convergence band cloud formed on the west coast of Hokkaido island. II: Cold frontal type. J. Meteor. Soc. Japan, 67, 985999.

Yagi, T., H. Uyeda, and H. Seino, 1979: Size distribution of snowflakes and graupel particles observed in Nagaoka, Niigata prefecture. J. Fac. Sci., Hokkaido Univ., Ser. VII, VI, 79-92.

Yoshizaki, M., T. Kato, H. Eito, A. Adachi, M. Murakami, S. Hayashi, and WMO-01 observation group, 2001: A report on "Winter MCSs (mesoscale convective systems) Observation over the Japan Sea in January 2001 (WMO-01)". Tenki, 48, 893-903 (in Japanese). 